\title{
Bối cảnh tài chính Việt Nam 1997-1998 và 2007-2008: khoảng cách và biến đổi
}

\author{
Phạm Minh Chính \\ Vương Quân Hoàng \\ Nghiên cứu Kinh tế \\ Vol. 48, No. 7, Serial 362, pp. 3-24
}

(ISSN: 0866-7489)

Ngày 15 tháng 7 năm 2008

Hà Nội, Việt Nam 


\title{
Bối cảnh tài chính Việt Nam 1997-1998 và 2007-2008: khoảng cách và biến đổi
}

\author{
PHẠM MINH CHÍNH \\ VƯơNG QUÂN HOẢNG
}

Tiến trình vận động của nền kinh tế ghi nhận các thời kỳ có nhiều xáo trộn nhu mốc đánh dấu khởi đầu của một giai đoạn phát triển mới. Các biến cố kinh tế tại Việt Nam trong nhũng năm 1997-1998 chịu ảnh hưởng lan truyền từ khủng hoảng tài chinh-tiền tệ của khu vực Đông Á, với tư cách một thành viên của kinh tế khu vực. Thay đổi kinh tế của một thập kỷ sau, 2007-2008, diễn ra cùng lúc với khủng hoảng tín dụng toàn cầu, bắt nguồn tù vấn nạn nợ dưới chuẩn nhà ở tại Hoa Kỳ và nhanh chóng phản ánh tiêu cực lên các hệ thống tài chính quốc tế, trong đó có Việt Nam. Bài viết tập trung phân tích các biến đổi rất đặc trưng về cấu trúc vĩ mô và sự tiến triển của các phương thức tương tác vi mô, qua hai giai đoạn có biến động kinh tế quan trọng bậc nhất của Việt Nam kể từ khi đổi mới, giai đoạn 1997-1998 và 2007-2008, cũng đánh dấu cho một thập kỷ tăng trưởng ổn định ở mức cao. Các tác giả hy vọng rằng nghiên cứu này có thể mở đường cho nhiều kiểm định thực chứng và nhấn mạnh việc đưa ra các quyết định vĩ mô sau này sát với các cấu trúc vi mô hơn; trong xu thế tất yếu, các cấu trúc vi mô đặc trưng cho kinh tế thị trường sẽ quyết địinh sự thành công của lứa chọn vĩ mô.

$\mathrm{K}$ inh tế Việt Nam bước vào năm 2007 với nhiều tín hiệu tích cực phát đi từ những tháng cuối năm 2006. Ngày 11-12007, Việt Nam chính thức trở thành thành viên thứ 150 của WTO - sự kiện đánh dấu mốc hoàn thành hành trình dài 12 năm kể từ ngày nộp đơn xin gia nhập. Thị trường chứng khoán (TTCK) Việt Nam bước sang tuổi thứ bảy cùng đà tăng nhanh chóng của chỉ số chứng khoán bắt đầu từ giữa năm 2006. Đầu năm 2007, VN-Index lần đầu được ghi nhận với 4 chũ số trong tháng 1 . $2007^{1}$ và đạt mức cao nhất trong lịch sử 1.171 điểm ngày 12-3-2007. Vốn đầu tư trực tiếp nước ngoài (FDI) đăng ký vào Việt Nam trong năm 2006 cũng cao nhất tính từ năm 1988: 10,2 tỷ USD- tăng gấp 2 lần so với một năm trước. Tăng trưởng GDP của năm 2006 dạt $8,17 \%$ mặc dù có giảm đi $0,26 \%$ so với năm 2005 nhưng vẫn ở trên mức bình quân $7,51 \%$ của giai đoạn 2001-2005.

Tuy thế, mầm mống sốc nội sinh bắt đầu xuất hiện ngay từ tháng 2-2007 khi các chỉ số tăng trưởng thị trường vốn và tiền tệ không thực sự phản ánh bản chất cải thiện năng lực của nền kinh tế (Hoàng, 2007a). Những dấu hiệu này ngày càng bộc lộ rõ trong những tháng tiếp theo, đặc biệt trên TTCK. Tổng mức vốn hóa của TTCK đạt tới qui mô $20 \%-30 \%$ GDP, chủ yếu do bùng phát bong bong giá tài sản tài chính. Theo thống kê của Sở Giao dịch chứng khoán thành phố Hồ Chí Minh, tới tháng 4-2008, 87 công ty chứng khoán, 30 công ty quản lý quỹ, 298.000 tài khoản đầu tư cá nhân - trong đó có trên 7.000 của nhà đầu tư nước ngoài, tham gia các giao dịch tài sản tài chính tại Việt Nam. Trong khi đó, một loạt những nhân tố căn bản cần thiết được đảm bảo lại bị coi nhệ, thậm chí bỏ qua. Các nhà đầu tư cá nhân tham gia TTCK với hiểu biết hạn chế. Truyền thông tài chính còn hạn chế cả

Phạm Minh Chính, Bộ Công an; Vương Quân Hoàng, Đại học Tổng hợp Bruxelles, Bỉ.

1. Kết thúc phiên giao dịch ngày 17-1-2007, VNIndex đạt 1012,7 điểm. 
về số lượng, trình độ xử lý và đảm bảo công bằng thông tin. Chăm sóc quan hệ với nhà đầu tư trở thành điểm nóng chỉ khi giá cổ phiếu bước sang thời kỳ sụt giảm kéo dài và vẫn bị nhầm lẫn, xếp cùng nhóm với hoạt động PR, quảng cáo của doanh nghiệp (Hoàng, 2007b). Các nguyên tắc quản trị và vấn đề xung đột lợi ích trong công ty đại chúng còn quá xa lạ. Nguồn lực huy động qua thị trường vốn được doanh nghiệp sử dụng tràn lan, kém hiệu quả vào các dự án mở rộng và lĩnh vực kinh doanh mới- nhiều nhất là bất động sản và tài chính-ngân hàng. Tăng trưởng nóng có dấu hiệu dựa vào "rent-seeking".

Sang năm 2008, kinh tế Việt Nam cùng lúc đô̂i mặt với nhiều thách thức lớn. TTCK giảm sút đẩy lùi chỉ số chứng khoán giao dịch tại Tp. Hồ Chí Minh về mức thấp nhất kể từ tháng 3-2006: 366 điểm của phiên giao dịch ngày 20-6-2008. Lạm phát trong ba tháng đầu năm vượt qua $9 \%$ và tăng lên tới $15 \%$ vào tháng $5-2008$ tác động trực tiếp tới đời sống của đông đảo dân cư. Hoạt động kinh doanh của cộng đồng doanh nghiệp gặp nhiều khó khăn khi giá đầu vào tăng cao, lãi suất vay vốn qua kênh ngân hàng ở mức trên $20 \% / n a ̆ m$. Cát giảm chi phí, kể cả nhân lực, trở thành vấn đề phổ biến tại đơn vị kinh doanh. Bản thân các ngân hàng thương mại và tổ chức tín dụng cũng gặp khó khăn trong thanh khoản, liên tiếp phải nâng lãi suất huy động tiền gửi, thậm chí, có lúc tới gần $20 \% / n a ̆ m$. Ngân hàng Nhà nước không dưới hai lần điều chỉnh tăng lãi suất cơ bản, lên tới $14 \% / n a ̆ m$ vào tháng sáu. Biên độ giao dịch tỷ giá hối đoái được nới rộng ra $\pm 2 \%$, đồng thời mức tỷ giá chính thức cũng được điều chỉnh tăng nhằm đối phó với áp lực gia tăng tỷ giá ngấp nghé 20.000 VND/USD trên thị trường. Thâm hụt thương mại sáu tháng đầu năm trên 14 tỷ USD.

\section{HİNH 1: Thâm hụt thương mại 6 tháng đầu năm 2008}

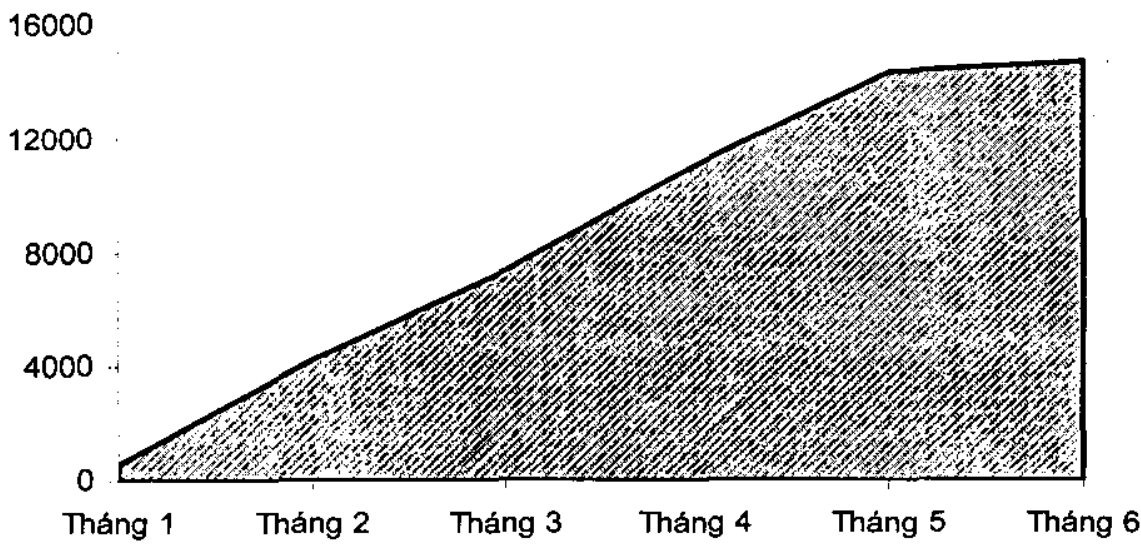

Nguồn: Tổng cục Thống kê, tháng 6-2008. Đơn vị: triệu USD

Chính những biểu hiện đó là nguyên nhân trực tiếp làm xuất hiện nhiều lo ngại và cả ý kiến phân tích đề cập tới khả năng một kịch bản tương tự với khủng hoảng tài chính-tiền tệ Châu Á năm 1997 lặp lại với Việt Nam trong tương lai gần. Tuy vậy, để trả lời câu hỏi liệu khủng hoảng có xảy ra hay không và nếu có sẽ theo cách nào, cần có những quan sát cẩn trọng những yếu tố kinh tế vĩ mô có xét tới bối cảnh của khu vực và thế giới, cùng cấu trúc, nguyên lý vận hành vi mô của hệ thống kinh tế.

Nghiên cứu này là kết quả của nỗ lực tập hợp dữ liệu nhằm so sánh các đặc trưng kinh tế của hai giai đoạn 1997-1998 và 2007-2008. Có những khác biệt rõ ràng trong từng yếu tố kinh tế căn bản như tăng trưởng, lạm phát, chính sách tiền tệ, thị trường tài chính, dòng vốn nước ngoài giữa hai thời kỳ. Câu chuyện của Thái Lan và 
Đông Á năm 1997 ít có cơ hội xuất hiện ở Việt Nam. Nghiên cứu cũng gợi mở hướng tiếp tục phát triển về mối quan hệ nhân quả giữa quyết sách vĩ mô và thực tế vận hành vi mô, vai trò của văn hóa và truyền thống kinh doanh trong các thời kỳ khó khăn kinh tế, tác động của truyền thông tới niềm tin của công chúng vào năng lực của hệ thống kinh tế và hiệu quả của công cụ chính sách.

\section{Cơ sở lỳ luận và mô hình}

Năm 1997, rối loạn tài chính dẫn tới dịch chuyển đột ngột kỳ vọng và niềm tin vào tiềm năng tăng trưởng kinh tế tại một số quốc gia Đông Á (Radelet và Sachs, 1998; Marshall 1998; Chang và Velasco, 1999) cùng các chính sách điều hành vĩ mô và cấu trúc kinh tế lệch lạc (Corsetti, Pesenti và Roubini, 1998; Dooley, 1999) được xem như hai nguyên nhân trực tiếp tạo thành khủng hoảng. Trong điều kiện Việt Nam của những năm 2007-2008, quan tâm nghiên cứu kinh tế và xã hội còn dành cho nỗ lực tìm kiếm giải pháp phù hợp trong xử lý mức giá tăng và duy trì tốc độ tăng trưởng ổn định thông qua các công cụ lãi suất và tỷ giá. Hiện diện của TTCK và dòng vốn đầu tư gián tiếp nước ngoài (FPI) là khác biệt lớn của hiện tại so với thời kỳ 1997-1998.

\subsection{Quan hệ tăng truởng-lạm phát}

Kinh tế học từ lâu đã quan tâm tìm hiểu mối quan hệ tăng trưởng và lạm phát. Có tồn tại quan hệ này không? Tương quan cùng chiều hay ngược chiều? Tác động qua lại giữa hai đại lượng này trực tiếp hay gián tiếp? Hiệu ứng tạo ra trong ngắn hạn hay dài hạn? là những câu hỏi thu hút đông đảo các nhà kinh tế học nỗ lực giải đáp. Trong khoảng 50 năm cuối của thế kỷ XX, nổi lên hai quan điểm: tăng trưởng cao trong giai đoạn lạm phát thấp trong thập kỷ 1960 và tăng trưởng cao đi liền với lạm phát cao trong thập kỷ 1980 .

Vào những năm 1960, lý thuyết kinh tế cổ điển cho rằng lạm phát cản trở tăng trưởng kinh tế trở nên kém thuyết phục với sự phổ biến của lý thuyết đường cong Phillips. Khi xem xét mối quan hệ giữa lạm phát và tỷ lệ thất nghiệp, nhà kinh tế $\mathrm{Phần}$ Lan Alban William Phillips đã chứng minh bằng thực nghiệm rằng trong nhũng giai đoạn tỷ lệ thất nghiệp thấp, nền kinh tế có mức lạm phát thấp và ngược lại. Nói cách khác, tăng trưởng kinh tế, sản phẩm được tạo ra nhiều hơn khi nhiều lao động được sử dụng hơn, có tương quan đồng biến dương (+) với lạm phát. Tobin và Sidrausky thậm chí còn đề xuất sự tồn tại của quan hệ này trong dài hạn. Khi lạm phát cao, của cải sẽ không được tích trũ dưới dạng tiền tệ mà tập trung vào các tài sản vật chất, từ đó, sản lượng xã hội có xu hướng gia tăng.

Những nghiên cứu thực nghiệm tại các nền kinh tế thuộc OECD, tuy vậy, lại đưa ra những bằng chứng không hẳn đã ưng hộ luận điểm trên (Harry G. Johnso, 1967). Nghiên cứu của Quỹ Tiền tệ quốc tế trong cùng giai đoạn này tại các quốc gia thành viên cũng kết luận không xác định được mối quan hệ giữa tăng trưởng và lạm phát về mặt thống kê. ${ }^{2}$ Vào năm 1969, Wallich tiến hành khảo sát thực nghiệm tại 43 quốc gia xem xét dũ liệu kinh tế trong 10 năm từ 1956-1965 với giả định ban đầu về tương quan dương giữa lạm phát và tăng trưởng kinh tế. Kết quả hoàn toàn ngược lại. Tương quan âm được chứng minh là có ý nghĩa thống kê.

Biến động kinh tế thế giới trong thập kỷ 1970 và 1980 ghi nhận thực tế về các mức lạm phát cao kỷ lục. Các quan sát trong thời kỳ này đi tới kết luận mức lạm phát cao nhưng ổn định không có tác động đáng kể đến sản lượng. Những nỗ lực kiềm chế lạm phát do những lo ngại mơ hồ mới thực sự khiến nền kinh tế phải trả giá. Quan điểm phổ biến trong thập kỷ 1980 là tồn tại quan hệ đồng biến giưa lạm phát và tăng trưởng trong ngắn hạn. Tình huống thực tế tại các quốc gia đang phát triển có mức lạm phát cao càng củng cố cho lập luận rằng nổ lực kiềm chế lạm phát tạo ra cản trở với tăng

2. Gờm các nghiên cứu của Wai (1959), Dorrance (1963 và 1966), và Bhatia (1960). 
trưởng kinh tế. Nghiên cứu của Ball (1993) tính toán được mức độ sụt giảm đáng quan sát của tăng trưởng kinh tế tại các quốc gia OECD trong nỗ lực bình ổn giá cả.

Các nghiên cứu lý thuyết cũng chỉ ra rằng mức lạm phát khi vượt quá một "ngưỡng giới hạn" sẽ tăng đột biến. Khi đó, không một hệ thống kinh tế nào có thể chịu đựng được mức giá cao và biến động, các biện pháp bình ổn buộc phải triển khai khẩn trương và mạnh mẽ. Do vậy, tình trạng lạm phát cao khó lòng là một trạng thái kéo dài trong nền kinh tế.

Mặt khác, nghiên cứu của Dornbusch và Fischer (1993) đi đến kết luận rằng một mức lạm phát trung gian trong khoản từ $15 \%$ đến $30 \%$ là có thể chấp nhận được trong thời gian tương đối dài mà không gây ra các tác động tiêu cực cho tăng trưởng.

Không có một mô hình hay lý thuyết duy nhất đúng để diễn đạt mỗi quan hệ giữa lạm phát và tăng trưởng. Tương quan này phải được xem xét cự thể với mổi điều kiện kinh tế, tại các thời điểm xác định.

Tháng 5-2008, Viện Nghiên cứu quản lý kinh tế trung ương công bố Báo cáo Kinh tế Việt Nam 2007 và đưa ra ba kịch bản dự báo cho năm 2008. Các chỉ tiêu kinh tế về tăng trưởng kinh tế, mức lạm phát cả năm và thâm hụt cán cân thương mại được ước lượng sẽ ở mức cơ bản $7,2 \%, 19,4 \%$ và $17,3 \%$ GDP. Trong tháng 4-2008, Ngân hàng Phát triển Châu Á đưa ra mức dự báo tăng trưởng $7 \%$ và lạm phát bình quân $18,3 \%$ cho năm 2008. Ngân hàng Thế giới, Quỹ Tiền tệ quốc tế, JETRO... cũng có các dự báo và nhận định lạc quan về tiềm năng phát triển trong dài hạn của kinh tế Việt Nam. Tuy vậy, các nghiên cứu và báo cáo này cùng không xem xét mối quan hệ' giữa tăng trưởng và lạm phát tại Việt Nam. Một số nhận định, nếu có, thì khá mờ nhạt.

\subsection{Ly thuyết tiền tệ về lạm phát}

Lạm phát thường được giải thích giản đơn là sự tăng giá qui mô rộng khắp của các hàng hóa thiết yếu. Cách tiếp cận này được chấp nhận phổ biến nhưng nỗ lực phân tích để giải quyết vấn đề theo cách này sẽ ít cho kết quả có giá trị ứng dụng. Tăng giá hàng hóa tiêu dùng tự thân nó không tạo ra áp lực liên tục đẩy mức giá cả chung lên cao. Giá một loại hàng hóa đột ngột tăng cao, đơn cử như giá dầu mỏ đã tăng thêm gần $50 \%$ kể từ đầu năm $2008 \mathrm{khi}$ có giá giao dịch 100 USD/thùng ${ }^{3}$, tạo ra hiệu ứng sốc tiêu cực về mặt cung. Nếu sốc đủ lớn, mặt bằng giá cả các loại hàng hóa tăng lên nhưng hiệu ứng này chỉ xảy ra trong một khoảng ngắn và dẫn tới cắt giảm sản lượng, việc làm. Cú sốc giá chỉ dẫn tới lạm phát khi và chỉ khi chính sách tiền tệ được sử dụng để mở rộng tín dụng với nỗ. lực hóa giải tác động tiêu cực tới sản lượng và việc làm. Trong tình thế đó, gốc rễ của lạm phát không phải sự tăng giá hàng hóa mà ở phản ứng của chính sách tiền tệ.

Mở rộng tiền tệ để đối phó với sự giảm từ phía cung dẫn tới lạm phát tăng cao nhưng không đi kèm với tăng trưởng sản lượng và việc làm tạo nên hiện tượng ứ phát (stagflation). Kinh tế thế giới đã chứng kiến hiện tượng này vào giữa thập kỷ 1970 khi OPEC tăng giá dầu lên gấp bốn lần (từ 3,6 USD/thùng năm 1971 lên 12,21USD/thùng năm 1975) và các quốc gia $\mathrm{OECD}$ cố gắng duy trì mức toàn dụng nhân công bằng chính sách tiền tệ nới lỏng. Tuy vậy, trong bối cảnh hiện tại của Việt Nam, không có bằng chứng xác nhận sự tồn tại của hiện tượng này ngoại trừ mức tăng giá đáng kể của giá dầu và lương thực. Lưu ý rằng Việt Nam là quốc gia xuất khẩu dầu thô.

Lý thuyết tiền tệ về lạm phát xem lượng tiền là một tỷ lệ với GDP danh nghĩa, diễn đạt bằng công thức:

$$
\mathrm{M}=\mathrm{kPY}
$$

trong đó $\mathrm{M}$ là cung tiền (bao gồm tiền trong lưu thông và tiền gửi ngân hàng), $P$ là chỉ số mức giá cả chung, $\mathrm{Y}$ là GDP thực tế và $k$ là tỷ lệ $\mathrm{GDP}$ danh nghĩa $(\mathrm{PY})$ được giữ

3. Trong phiên giao dịch ngày 30-6-2008, giá dầu thô ngọt nhẹ giao tháng 8-2008 trên thị trường New York là 143,67 USD/thùng (www.asset.vn). 
bằng tiền. Nếu giả định $\mathrm{k}$ là một hằng số thì lạm phát (xác định bằng $\Delta \mathrm{P} / \mathrm{P}$ ) là phần chênh lệch giữa tăng trưởng cung tiền $(\Delta \mathrm{M} / \mathrm{M})$ và tăng trưởng GDP thực tế $(\Delta \mathrm{Y} / \mathrm{Y})$

\section{$\Delta \mathrm{P} / \mathrm{P}=\Delta \mathrm{M} / \mathrm{M}-\Delta \mathrm{Y} / \mathrm{Y}$}

Nói cách khác, lạm phát là phần chênh lệch giữa tốc độ tăng cung tiền - quyết định bởi chính sách tiền tệ và cầu tiền - quyết định bởi tốc độ tăng trưởng của các hoạt động kinh tế.

Điểm đáng lưu ý là trong một nền kinh tế chuyển đổi như Việt $\mathrm{Nam}$, giả thiết $k$ là hằng số sẽ không hợp lý. Hệ số $k$ sẽ lớn hơn khi tỷ trọng giao dịch sử dụng tiền mặt so với giao dịch trao đổi hàng hóa hay phân phối theo mệnh lệnh tăng lên. Đô thị hóa nhanh chóng cũng làm $k$ tăng lên do cư dân thành thị sử dụng nhiều giao dịch trao đổi tiền tệ hơn những người sinh sống tại nông thôn. Thêm nữa, trong tình cảnh tài chính ngặt nghèo, lãi suất tiết kiệm tăng cao sẽ kéo nhu cầu gửi tiền vào ngân hàng lên theo. Số liệu thống kê của IMF cho biết cầu tiền (chủ yếu là tiền gửi ngân hàng) tại Việt Nam đang tăng trưởng nhanh hơn rất nhiều so với các hoạt động kinh tế. Tỷ số M2/GDP là $20 \%$ vào năm 1996 và liên tục tăng kể từ đó cho tới mức xấp xỉ $100 \%$ vào năm 2007 .

\subsection{Chính sách tiền tệ và tài khóa}

Chính sách tiền tệ và tài khóa là hai công cụ chủ chốt được chính phủ sử dụng duy trì tốt độ tăng trưởng ổn định trong tương quan hợp lý với lạm phát (Dornbush và Fischer, 1992). Có đối tượng tác động trực tiếp là các thị trường tài sản và hàng hóa nhưng hai chính sách này kết nối chặt chẽ thông qua một cơ chế truyền dẫn kinh tế vĩ mô, trong đó thay đổi chính sách tiền tệ tác động tới tổng cầu mang tính cốt yếu.

Cơ chế truyền dẫn gồm hai giai đoạn. ở giai đoạn đầu tiên, cân bằng vật chất trong nền kinh tế tăng lên (kết quả của một thời kỳ tăng trưởng) tạo ra mất cân bằng với danh mục tài sản, thể hiện phổ biến qua lãi suất và mức thu nhập. Các thực thể kinh tế nắm giữ nhiều tiền hơn mức mong muốn. Do vậy, họ nỗ lực giảm lượng tiền đang có bằng việc mua những tài sản khác. Việc này dẫn tới thay đổi giá và mức sinh lời của tài sản. Nói cách khác, biến đổi cung tiền làm thay đổi lãi suất. Giai đoạn truyền dẫn thứ hai xuất hiện khi thay đổi lãi suất tác động tới tổng cầu. Mức lãi suất cao hơn thường dẫn tới hành vi cắt giảm tiêu dùng và tăng tiết kiệm.

Tác động của chính sách tiền tệ tới nền kinh tế có hai thái cực đáng chú ý. Bây thanh khoản là trạng thái trong đó công chúng được chuẩn bị để nắm giữ toàn bộ lượng cung tiền tại mức lãi suất xác định. Lúc này các điều tiết chính sách tiền tệ trên thị trường mở không tạo ra bất kỳ tác động nào tới lãi suất. Nếu vì một lý do nào đó lãi suất trên thị trường bằng 0 hoặc có mức thực dương thấp, các chính sách tiền tệ sẽ không hoạt động. Chỉ số giá 3 tháng đầu năm 2008 so với cùng kỳ năm trước tăng hơn $16 \%$ trong lúc lãi suất cơ bản được áp dụng ở mức $8,75 \%$ có thể xem như nguyên nhân khiến các động thái bổ sung hay rút bớt tiền trong lưu thông của Ngân hàng Nhà nước trong tháng 2 và 3 năm 2008 không đạt tới mục tiêu điều chỉnh lãi suất như mong muốn.

\section{BẢNG 1: So sánh mức tăng chỉ số giá tiêu dùng và lãi suất cơ bản 2008}

\begin{tabular}{|c|c|c|}
\hline & $\begin{array}{c}\text { Chỉ số giá so với cùng kỳ } \\
\mathbf{2 0 0 7}\end{array}$ & $\begin{array}{c}\text { Lãi suất cơ } \\
\text { bản }\end{array}$ \\
\hline $\begin{array}{c}\text { Ba tháng đâu năm } \\
2008\end{array}$ & $16,38 \%$ & $8,75 \% /$ năm \\
\hline $\begin{array}{c}\text { Sáu tháng đâuu năm } \\
2008\end{array}$ & $20,34 \%$ & $14 \%$ /năm \\
\hline
\end{tabular}

Nguồn: Tỏng cục Thống kê và Ngân hàng Nhà nước, 2008. 
Khi lãi suất giảm xuống, hoạt động đầu tư có $x u$ hướng gia tăng. Doanh nghiệp chuẩn bị các dự án mới với nguồn tài trợ từ các khoản vay ngân hàng. Tuy nhiên, với mức lãi suất thực tế thấp, ngân hàng thương mại rất miễn cưỡng cung cấp tín dụng, thậm chí từ chối tài trợ. Nguyên nhân sâu xa của hành vi này thường là những khoản nợ xấu tồn đọng từ thời kỳ trước. Chuyện này đã xảy ra với nền kinh tế Mỹ trong thập kỷ 1990 khi Fed cắt giảm lãi suất và các ngân hàng vướng vào sụp đổ của thị trường bất động sản (1990-1991) đã từ chối nhiều khoản vay mới để tìm đến các tài sản ít rủi ro như trái phiếu và tín phiếu chính phủ. Khi này, điều tiết tiền tệ trên thị trường mở sẽ không có tác dụng đáng kể. Nghiên cứu của Bernake và Lown (1991) đi đến kết luận ngân hàng lựa chọn quyết định cắt giảm tín dụng cho khu vực kinh tế tư nhân. Tuy vậy, cũng có những ý kiến cho rằng tiếp tục đẩy mạnh các động thái trên thị trường mở rốt cuộc sẽ dẫn tới mức giảm sâu hơn của lãi suất và nền kinh tế sẽ chuyển động trở lại. Nói cách khác, khi việc cắt giảm lãi suất không tạo ra đủ tác động thì cần cắt giảm mạnh mẽ hơn.

Mức cung tiền trong nền kinh tế được Dornbush và Fischer thể hiện qua phương trình:

$$
M=\frac{1+c u}{r e+c u} H=m m\left(i, i_{D}, i_{R}, c u, \delta\right) H
$$

Trong đó $m m$ - số nhân tiền tệ, là một hàm của lãi suất (i), lãi suất chiết khấu $\left(i_{D}\right)$, dự trũ bắt buộc $\left(i_{R}\right)$, tỷ lệ tiền/tiền gửi $(c u)$ và tốc độ biến động của dòng tiền gửi. Với lượng tiền cơ sở $\mathrm{H}$, cung tiền sẽ thay đổi tùy thuộc vào số nhân tiền tệ. Ngân hàng trung ương thông thường tác động vào cung tiền thông qua ba công cụ: tiền cơ sở $(\mathrm{H})$ bằng hoạt động thị trường mở, lãi suất chiết khấu, tỷ lệ dự trũ bắt buộc. Tại Việt Nam, Ngân hàng Nhà nước có thể điều chỉnh mức lãi suất cơ bản được công bố hàng tháng và biên độ dao động lãi suất.

Chính sách tài khóa mở rộng nâng cao sản lượng cân bằng và mặt bằng lãi suất của nền kinh tế. Khi lãi suất không đổi, đẩy mạnh chi tiêu chính phủ làm tăng tổng cầu. Để đáp ứng phần nhu cầu mới, sản lượng của nền kinh tế cũng tăng lên. Tuy vậy, thị trường hàng hóa không có khả năng điều chỉnh nhanh chóng như thị trường tiền tệ, cần một khoảng thời gian đủ dài để có thể điều chỉnh mức sản lượng cung cấp cho xã hội. Hiệu ứng nổi bật của chính sách tài khóa là sự lấn át của đầu tư công đối với khu vực kinh tế tư nhân. Phạm vi nghiên cứu này, với hạn chế thời gian và dũ liệu có thể tập hợp, không đi sâu vào các vấn đề chi tiêu chính phủ và hiệu quả đầu tư công.

\subsection{Thị trường chứng khoán và dòng vốn nước ngoài}

Ra đời tháng 7-2000, TTCK tạo sự khác biệt rất lớn giữa hai giai đoạn 1997-1998 và 2007-2008. Một kênh huy động vốn mới xuất hiện. Vai trò của TTCK với tổng thể kinh tế vĩ mô và hệ thống tài chính có điểm khác biệt quan trọng. TTCK là nhân tố quan trọng bậc nhất trong hệ thống tài chính trên khía cạnh phản ánh các quyết định đầu tư của doanh nghiệp. Ngược lại, các chính sách và mô hình kinh tế vĩ mô không đặt nặng vai trò quyết định đầu tư của thị trường này mà chú ý tới khả năng phản ánh trạng thái của chu kỳ kinh doanh (Fischer và Merton, 1984).

Tuy vậy, phát triển của TTCK được xem xét như động lực thúc đẩy tăng trưởng của cả hệ thống tài chính và toàn bộ nền kinh tế (Caporale et.al., 2004). TTCK hoạt động tốt góp phần khuyến khích tiết kiệm và phân bổ nguồn vốn hợp lý cho các dự án đầu tư có hiệu suất cao, từ đó, nâng cao tốc độ tăng trưởng kinh tế. Thông qua giao dịch trên TTCK, nhà đầu tư có phương tiện chia sẻ rủi ro thanh khoản khi bỏ vốn vào các dự án. Khi một nhà đầu tư gặp phải vấn đề khả năng thanh khoản, người này có thể bán cổ phiếu đang nắm giữ cho nhà đầu tư khác đang ở trạng thái tải chính khỏe mạnh. Nhờ vậy, dòng vốn đầu tư không rời khởi dự án/doanh nghiệp để đáp ứng các nhu cầu tài chính cá nhân. 
Phân phối nguồn lực tài chính qua TTCK có tác động trực tiếp tới tổng thể hệ thống kinh tế. Tài trợ dự án qua con đường vay nợ gặp nhiều khó khăn tại các quốc gia đang phát triển. Những khoản vay từ ngân hàng thương mại chỉ dành cho một nhóm doanh nghiệp và cá nhân thỏa mãn tập hợp điều kiện nhất định. Bởi vậy, có quan điểm cho rằng cần đặt ưu tiên phát triển TTCK lên trên nỗ lực tự do hóa hệ thống ngân hàng trong giai đoạn đầu của quá trình chuyển sang kinh tế thị trường (McKinnon, 1989), nhất là trong các tình huống hệ thống ngân hàng đang gặp phải vấn đề nợ xấu. Khảo sát tại 5 quốc gia đang phát triển của Arestis, Demetriades và Luintel (2001) về mối quan hệ giũa mức độ phát triển của TTCK và tăng trưởng kinh tế trong điều kiện kiểm soát tác động của hệ thống ngân hàng và biến động của TTCK cung cấp kết luận rằng: hoạt động hiệu quả của TTCK góp phần thúc đầy tăng trương kinh tế, nhưng ở mức độ thấp hơn so với hệ thống ngân hàng. Từ góc độ tăng trưởng tiền tệ, TTCK phát triển cung cấp phương tiện để triển khai hiệu quả chính sách tiền tệ thông qua phát hành và mua lại các loại chứng khoán của chính phủ trên thị trường có tính thanh khoản cao.

Khi chưa có TTCK, dòng vốn nước ngoâi đi vào Việt Nam chỉ duy nhất băng hình thức FDI nhưng đã chứng tỏ là động lực quan trọng thúc đẩy tăng trưởng kinh tế. Trong giai đoạn 1992-1997, vốn đầu tư nước ngoài đóng góp từ $5 \%$ đến $10 \%$ GDP hàng năm. Khoảng 700 -triệu USD vốn đầu tư gián tiếp nước ngoài đã vào Việt Nam cùng tám quỹ đầu tư hoạt động trong những năm đầu thập kỷ 1990. Nhưng khó khăn trong tìm kiếm cơ hội bỏ vốn, qui mô thị trường nhỏ, tính thanh khoản thấp và tác động của khủng hoảng 1997 đã chuyển hướng dòng vốn này ra khỏi Việt Nam. Chỉ tới khi TTCK có phát đỉ tín hiệu khởi sắc vào năm 2005 , các nhà đầu tư tài chính quốc tế mới thể hiện rõ ràng quan tâm với tiềm năng của Việt Nam (Hoàng và Dũng, 2008).

\section{Dũ liệu và so sánh}

Những năm 1997-1998, vấn đề vĩ mô được đặt lên hàng đầu tại Việt Nam là xóa đói giảm nghèo, dịch chuyển hướng vận động kinh tế tiếp cận gần hơn với dòng chảy của khu vực và quốc tế. Sau một thập kỷ, khi đời sống nhân dân cải thiện rõ rệt, quá trình hội nhập triển khai nhanh chóng và toàn diện, trước những thách thức xuất phát từ biến động kinh tế trong nước và quốc tế, các nhà quản lý và điều hành kinh tế vĩ mô dành mối quan tâm cho các vấn đề nền tảng mới: duy trì tăng trưởng ổn định và kiềm chế lạm phát, và tính bền vững của hệ thống tài chính bao gồm các TTCK, tiền tệ, ngoại hối và dòng vốn nước ngoài.

\subsection{Tăng trưởng và lạm phát}

Đầu thập kỷ 1990, mức lạm phát cao được các nhà kinh tế chấp nhận như một hệ quả của quá trình chuyển đổi sang kinh tế thị trường. Nhờ cắt bớt chi tiêu chính phủ và kiềm chế tăng trưởng tín dụng tốt, tốc độ lạm phát đã giảm đi đáng kể vào cuối những năm 1990, trong khi tốc độ tăng trưởng kinh tế vẫn tiếp tực được duy trì.

Trong hai năm 1997-1998, mức tăng lên hàng năm của chỉ số giá tiêu dùng không vượt quá một con số. Chỉ số giá tiêu dùng tháng 12-1997 cao hơn với cừng kỳ năm trước $3,6 \%$. Năm 1998, mức này là $9,2 \%$. Chênh lệch giá tiêu dùng giữa các tháng trong năm không nhiều, vận động theo cả hai hướng tăng lên và giảm đi. Sau Tết âm lịch, chỉ số giá tiêu dùng có xu hướng giảm xuống. Chỉ số giá tiêu dùng so với tháng trước vào tháng ba của các năm 1996 và 1997 đều giảm, lần lượt là $2,3 \%$ và $3 \%^{4}$.

Việt Nam đạt tốc độ tăng trưởng kinh tế cao - bình quân $9 \%$ mỗi năm, trong giai đoạn 1992-1997. Động lực tăng trưởng trước tiên gắn liền với mức đầu tư và tăng trưởng công nghiệp cao, được hỗ trợ mạnh mẽ từ nguồn vốn đầu tư trực tiếp nước ngoài lên tới 2 tỷ USD mỗi năm, đã đóng góp từ 5-10\% GDP

4. Tính toán từ sớ liệu chỉ só giá tiêu dùng các tháng trong năm 1995-2006, Tởng cục Thống kê. 
hàng năm. Trong năm 1997, nguồn vốn hỗ trợ phát triển cũng giải ngân được tới 1 tỷ USD. Sản lượng và xuất khẩu dầu năm 1997 tăng lên 1,4 tỷ USD, gấp gần hai lần con số 750 triệu USD của năm 1992. Nông nghiệp cũng tiếp tục tiến lên với tốc độ $4-5 \%$ mỗi năm. Việt Nam trở thành nước xuất khẩu gạo và cà phê quan trọng trên thị trường quốc tế.

Kim ngạch xuất khẩu của Việt Nam đã tăng từ 2 tỷ USD năm 1991 lên gấp hơn 4 lần sau 6 năm. Giá trị xuất khẩu năm 1997 là gần 9,2 tỷ USD. Tuy vậy, cuộc khủng hoảng tài chính-tiền tệ Châu Á cũng khiến bước tiến của kinh tế Việt Nam chậm lại. Tốc độ tăng trưởng GDP trên đầu người $6-7 \%$ trong những năm 1990-1997 đã không thể tiếp tục duy trì và giảm xuống còn $4 \%$ vào giai đoạn 1998-1999 . Khó khăn tài chính của khu vực làm giảm lượng vốn FDI từ các nhà đầu tư láng giềng và khiến nhiều dự án lâm vào trạng thái dở dang. Trị giá xuất khẩu năm 1998 đạt 9,3 tỷ USD, tăng không đáng kể so với năm trước. Trong các năm 1995 và 1996, giá trị xuất khẩu đều đạt tốc độ tăng trưởng cao, lần lượt là $30 \%$ và $27 \%$.

\section{HİNH 2: Giá trị xuất, nhập khẩu của Việt Nam: 1995-2008}

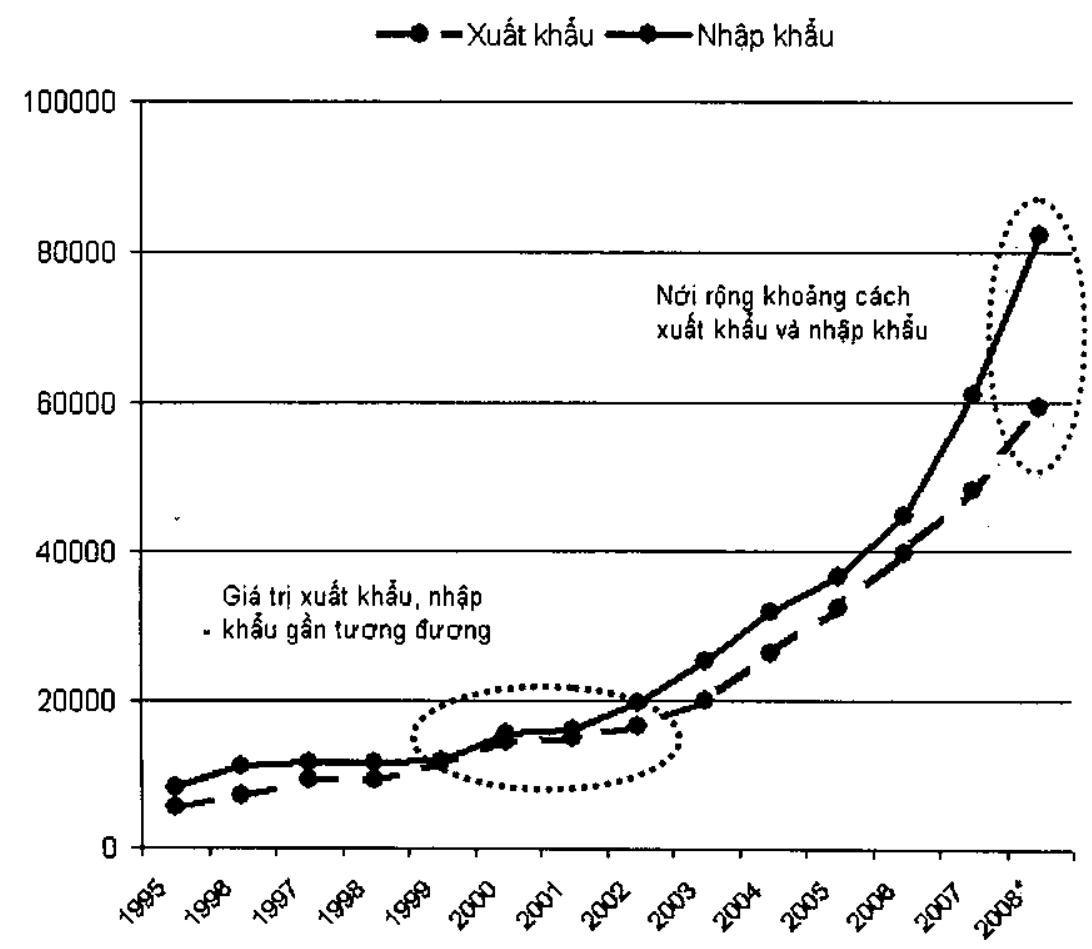

Nguồn: Tổng cục Thống kê. Đơn vị: triệu USD

Kể từ năm 2000, tăng trưởng kinh tế của Việt Nam ổn định ở mức $7-8 \% / n a ̆ m$. Mức lạm phát cũng liên tục tăng lên trong cùng thời gian. Cuối năm 2007, mức hai con số $(12,6 \%)$ trở lại kể từ những năm cuối thập kỷ 80 , đầu thập kỷ 90 . Lo ngại này càng tăng lên khi chỉ số giá cả không ngừng đi lên trong nửa đầu năm 2008. Chỉ số giá tiêu dùng của 6 tháng đầu năm 2008 tăng $20 \%$ so với cùng kỳ năm $2007^{6}$.
Chỉ số giá tăng cao của năm 2008 khiến các lựa chọn chính sách trở nên khó khăn hơn trong điều kiện ràng buộc với giữ ổn định tốc độ tăng trưởng kinh tế, với nhiêu thay đổi căn bản của hệ thống kinh tế.

5. David O. Dapice, 2001. An overview of the Vietnamese economy after the Asian crisis., John F. Kennedy School of Government, Harvard University.

6. Tổng cục Thống kê, tháng 6-2008, 


\section{HÌNH 3: Tăng trưởng GDP thực tế và lạm phát 2002-2007 (đơn vị: \%)}

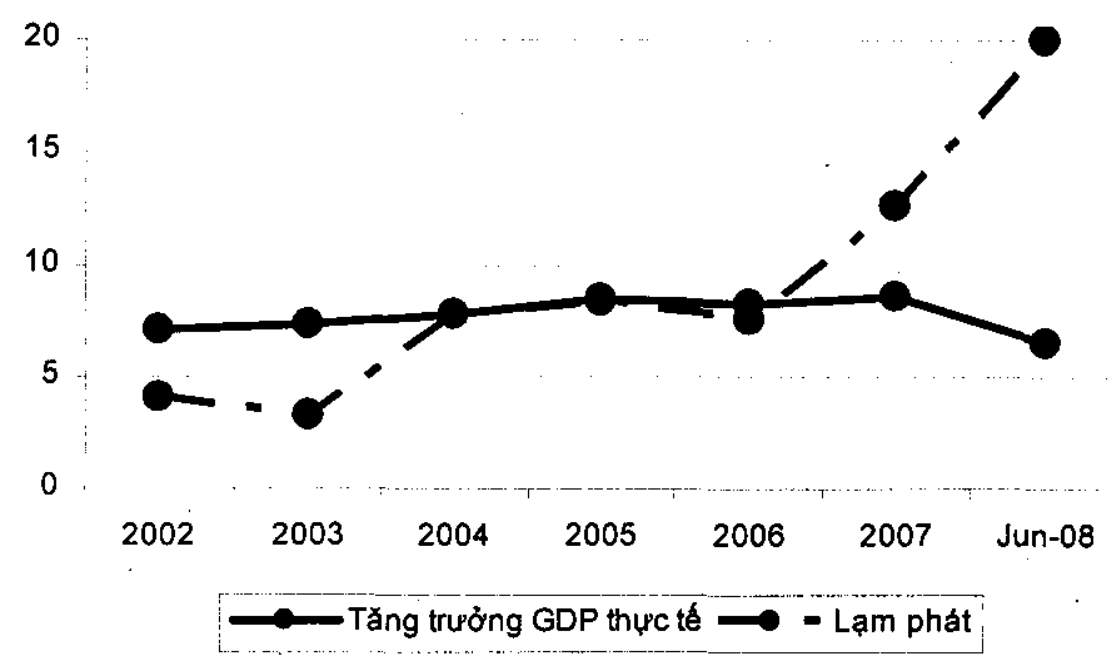

Nguồn: Só liệu thớng kê IMF, www.asset.vn

Vai trò của thị trường ngày càng mở rộng. Hoạt động kinh tế được tiền tệ hóa rộng rãi. Với tư cách thành viên chính thức của WTO, Việt Nam mở rộng cửa với các hoạt động thương mại, dịch vụ và đầu tư nước ngoài. Cấu trúc sản xuất và việc làm dịch chuyển sang các lĩnh vực sử dụng nhiều nhân công, định hướng xuất khẩu. Kinh tế tư nhân nổi lên mạnh mẽ cùng với $\mathrm{khu}$ vực kinh tế có vốn đầu tư nước ngoài. Hệ thống tài chính phát triển mau chóng nhờ sự hiện diện của TTCK và hàng loạt ngân hàng thương mại, tổ chức tài chính tư nhân (trong nước và quốc tê). Kết quả là các loại giá cả tương đối - tiền lương thực tế, tỷ giá hối đoái thực tế và lãi suất thực tế đều nhạy cảm với lạm phát, có ảnh hưởng lớn hơn rất nhiều tới chia sẻ nguồn lực, phân phối thu nhập và hiệu quả chung của nền kinh tế so với thời điểm 10 năm trước. Những thành quả phát triển và quốc tế hóa nền kinh tế đang đặt những nhà lãnh đạo và điều hành kinh tế vĩ mô Việt Nam trong một tình thế phức tạp hơn rất nhiều so với kinh nghiệm giải quyết lạm phát trong quá khứ.

\section{Cam kết về mở cửa thị trường dịch vụ tài chính của Việt Nam trong WTO về hiện diện thương mại của tổ chức tài chinh-tín dụng nước ngoài}

Đối với ngân hàng thương mại nước ngoài: văn phòng đại diện, chi nhánh, ngân hàng thương mại liên doanh với số vốn đầu tư chiếm không quá $50 \%$, công ty cho thuê tài chính, công ty liên doanh tài chính và công ty tài chính $100 \%$ vốn nước ngoài. Từ ngày 1-4-2007 ngân hàng $100 \%$ vốn đầu tư nước ngoài được phép thành lập.

- Đối với công ty tài chính nước ngoài: văn phòng đại diện, công ty tài chính liên doanh và $100 \%$ vốn nước ngoài, công ty cho thuê tài chính liên doanh và $100 \%$ vốn nước ngoài.

- Đối với công ty cho thuê tài chính nước ngoài: văn phòng đại diện nước ngoài, công ty liên doanh và $100 \%$ vốn nước ngoài. 
Trong khi tăng trưởng cung tiền tạo ra lạm phát tại Việt Nam, biến động giá ngoại sinh cũng đóng góp đáng kể vào mức giá tăng cao vừa qua. Do đó, tách biệt phần đóng góp của các hiệu ứng mở rộng tiền tệ ở mặt cầu và cú sốc giá ngoại sinh ở mặt cung sẽ rất hữu ích trong việc xác định cụ thể nguyên nhân và giải pháp xử lý lạm phát. Khó khăn chủ yếu của cách tiếp cận này nằm ở việc tập hợp đầy đủ các số liệu thống kê tin cậy ở mức cần thiết.

\subsection{Thị trường chứng khoán}

Trong 5 năm hoạt động đầu tiên, qui mô TTCK mở rộng với tốc độ khiêm tốn. Tư 2 mã cổ phiếu đầu tiên: SAM và $R E E$ trong giai đoạn 2002-04, thị trường niêm yết thêm $6 \mathrm{mã}$ cổ phiếu. Cùng với sự ra đời của Trung tâm Giao dịch chứng khoán Hà Nội (HaSTC), số lượng doanh nghiệp niêm yết cổ phiếu trên TTCK bắt đầu tăng nhanh kể từ năm 2005. Tính riêng 12 tháng của năm 2006 đã có thêm 146 cổ phiếu niêm yết mới, gấp hơn ba lần số tích lũy của cả 5 năm trước. Đến cuối tháng 6-2008 có 299 cổ phiếu và chứng chỉ quỹ được giao dịch trên các sàn chứng khoán.

Số lượng tổ chức trung gian tài chính tăng nhanh chóng từ chưa tới 20 công ty chứng khoán trong những năm 2004-2005, đến đầu năm 2008, thống kê sơ bộ của HOSE cho biết có 87 công ty chứng khoán và 30 công ty quản lý quỹ đang hoạt động. Đông đảo các nhà đầu tư trong nước và quốc tế tham gia giao dịch chứng khoán, với xấp xỉ 298.000 tài khoản vào cuối năm 2007, trong đó có trên 7.000 của nhà đầu tư nước ngoài, tăng gần $300 \%$ so với năm trước (2006: 106.000 tài khoản $)^{7}$.

$\mathrm{Xu}$ thế tăng mạnh của VN-Index được duy trì từ cuối 2006 đến nửa đầu 2007. Đầu năm 2007, VN-Index được ghi với bốn chũ số lần đầu tiên sau phiêu giao dịch ngày 17-1. 2007: 1012,7 điểm. Liên tục tháng hai, tháng ba và cả nửa đầu tháng tư, chỉ số chung của thị trường ở trên mức 1.000 .
Ngày 12-3-2007, VN-Index là 1.171 điểm . mức cao nhất trong lịch sử TTCK Việt Nam.

Nửa cuối năm 2007, TTCK Việt Nam sụt giảm với hai trạng thái phổ biến: giảm sàn hoặc tăng không đáng kể. Đã có một vài đợt phục hồi trong những tháng cuối năm 2007 nhưng tới đầu năm 2008, TTCK thời kỳ suy giảm trầm trọng, xóa sạch những thành tích tăng trưởng của hai năm trước đó. Chỉ số chứng khoán xuống dưới 400 điểm lần đầu tiên vào ngày 4-6-2008 (395) và tiếp tục lùi gần về mức chỉ số của đầu năm 2006.

Biến động đảo chiều của TTCK gây tác động tâm lý tiêu cực cho các nhân tố tham gia thị trường, đặc biệt nhà đầu tư cá nhân. Khi thị trường ở trạng thái cao trào, số tiền tích lũy của một cá nhân trở nên không đủ lớn để tìm kiếm mức lợi nhuận đáng kể từ kinh doanh chứng khoán. Từng nhóm cá nhân cùng nhau góp vốn, huy động cá nhân, vay ngân hàng để hình thành lượng đầu tư đáng kể tham gia thị trường. Bởi vậy, khi giá cổ phiếu đồng loạt đi xuống, áp lực thu hồi vốn, thanh toán nghĩa vụ tín dụng đè nặng lên một số đông lớn hơn nhiều lần số tài khoản giao dịch chứng khoán thống kê được.

Suy giảm trong 3 tháng đầu năm 2008 đưa chỉ số TTCK Việt Nam về lại mức tương đương của năm 2006. Các phản ứng tiêu cực và thái quá từ công chúng đầu tư hoàn toàn có thể hiểu được, nhưng đó cũng chính là những dấu hiệu bất ổn cần đặc biệt lưu tâm, kèm theo các xung đột và tranh chấp lợi ích tài chính tiềm tàng, gay gắt và ở quy mô rộng khắp (Chính và Hoàng, 2008).

Tác động của các biến động trên TTCK không giới hạn trong phạm vi các giao dịch tài sản tài chính mà lan tỏa nhanh chóng, mạnh mẽ sang các thị trường bất động sản và tín dụng (Hoàng và Sơn: 2008). Tăng trưởng bùng nổ của TTCK vào cuối năm 2006 đã

7. Thống kê của Sở Giao dịch chứng khoán thành phố Hồ Chí Minh, tháng 4-2008. 
mang lại những khoản lãi đáng kể cho các nhà đầu tư, bằng cả tiền mặt và ghi nhận trên sổ sách. Yếu tố tâm lý và đặc tính truyền thống văn hóa lái một phần đáng kể những lợi nhuận này sang thị trường bất động sản. Trong quí I - 2007, mức cầu bất động sản tăng vọt. Lượng tiền mặt thu được từ lợi nhuận trên TTCK không chỉ góp phần tăng số lượng giao dịch và còn tạo tính thanh khoản rất cao cho thị trường này. Đây được xem như một trong những nguyên nhân trực tiếp nhất dẫn tới cơn sốt bất động sản trong quãng thời gian còn lại của năm 2007. Giá bất động sản tiếp tục tăng cao trong quí II. 2007. Và ngay cả khi TTCK bước vào thời kỳ suy thoái ở nửa sau 2007, bất động sản vẫn được nhiều nhà đầu tư lựa chọn như một giải pháp thay thế ưa thích cho các loại chứng khoán. Dấu hiệu thua lỗ từ các khoản đầu tư bất động sản xuất hiện vào đầu năm 2008 khi cùng lúc hai TTCK và tiền tệ gặp khó khăn, đặc biệt là về khả năng thanh khoản. Phiên giao dịch ngày 9-6-2008 đã kết thúc với khối lượng giao dịch thấp nhất kể từ đầu năm 2006 tại HOSE: 905.502 đơn vị; giao dịch chỉ đạt 25,9 tỷ đồng.

Tăng trưởng nóng của TTCK kéo theo tốc độ mở rộng tín dụng nhanh chóng tại các ngân hàng thương mại tập trung vào khách hàng là nhà đầu tư tài chính. Đặt kỳ vọng cao vào $x u$ thế tăng giá chứng khoán liên tục, vốn được huy động từ nhiều nguồn đổ về TTCK, để rồi các tải sản tài chính lại được cầm cố tại ngân hàng thương mại và tiếp tục bổ sung một lượng tiền mới cho thị trường vốn. Tính riêng tại ngân hàng $\mathrm{ACB}$, trong quí $\mathrm{I}-2007$, doanh số cho vay cầm cố chứng khoán đã tăng $30 \%$ so với cùng kỳ năm 2006. Để đảm bảo an toàn và ổn định cho hệ thống tín dụng-ngân hàng, ngày 28-5-2007, Ngân hàng Nhà nước đã ban hành Chỉ thị số 03 với nội dung quan trọng là hạn mức cho vay đầu tư chứng khoán của các ngân hàng thương mại không được vượt quá $3 \%$ tổng dư nợ. Thị trường có nhiều phản ứng và ý kiến trái chiều với động thái siết chặt tín dụng của hệ thống ngân hàng, tuy vậy, tác dụng kìm hãm hưng phấn quá mức với hoạt động kinh doanh chứng khoán được ghi nhận.

Khả năng huy động nguồn lực xã hội qua TTCK và các khoản thặng dư vốn cổ phần lớn ${ }^{8}$ hình thành động lực trực tiếp để các doanh nghiệp đầu tư mở rộng qui mô sản xuất và bước sang các lĩnh vực kinh doanh mới. Lĩnh vực thu hút quan tâm gồm tài chính-ngân hàng, chứng khoán và bất động sản. Tâm lý lạc quan vào triển vọng phát triển kinh tế còn cho phép các chủ đầu tư huy động vốn cổ phần và tìm kiếm thặng dư vốn trên cả những dự án mới. Một làn sóng đầu tư mới lại dồn về TTCK, nhưng lúc này, rủi ro cao hơn do tỷ trọng giao dịch cổ phần trên thị trường phi tập trung (còn gọi lả OTC) tăng lên. Đây là đặc điểm rất khác với hoàn cảnh kinh tế của giai đoạn 1997-1998.

\subsection{Lãa suất}

Cơ chế lãi suất của Việt Nam dần dịch chuyển từ kế hoạch hóa tập trung, thoát ly lãi suất của nền kinh tế thế giới sang điều chỉnh linh hoạt, từng bước tự do hóa, hội nhập với hệ thống tài chính toàn cầu. Cải cách trong hệ thống ngân hàng được đánh dấu bằng Nghị định 53/HĐBT ngày 26-31988 phân định rõ ràng chức năng, nhiệm của Ngân hàng Nhà nước và các ngân hàng chuyên doanh, làm tiền đề cho Pháp lệnh về Ngân hàng Nhà nước và Pháp lệnh về ngân hàng, hợp tác xã tín dụng và công ty tài chính. Có hiệu lực kể tư ngày 1·10-1990, hai Pháp lệnh đã tạo lập mô hình ngân hàng hai cấp. Trong đó, Ngân hàng Nhà nước Việt Nam thực hiện chức năng ngân hàng của các ngân hàng, quản lý hoạt động kinh doanh của các ngân hàng thương mại, các tổ chức tín dựng trong nền kinh tế; các ngân hàng thương mại, tổ chức tín dựng thực hiện chức năng kinh doanh trực tiếp trên linh vực tín dụng, tiền tệ và cung cấp dịch vụ ngân hàng.

8. Nhiều cổ phiếu được giao dịch với mức giá cao gáp cả chục làn mệnh giá. Cá biệt có cở phiếu được giao dịch ở giá gấp trên 65 lần như FPT (ngày 27-2-2007). 
Trần lãi suất được điều hành linh hoạt trong thời kỳ từ năm 1996 đến tháng 72000. Ngân hàng Nhà nước cũng bước đầu thực hiện tự do hóa lãi suất huy động. Thay thế cho khung lãi suất tối thiếu về tiền gửi và tối đa về tiền vay, Ngân hàng Nhà nước chỉ qui định các mức lãi suất "trần" theo thời hạn cho vay và khống chế chênh lệch giữa lãi suất cho vay và lãi suất huy động vốn bình quân là $0,35 \%$ /tháng (tương đương $4,2 \% / n a ̆ m$ ). Qui định này nhằm khắc phục tình trạng hầu hết các ngân hàng thương mại đều có mức lợi nhuận cao trong khi doanh nghiệp đang gặp nhiều khó khăn do biến động kinh tế khu vực. Tới cuối tháng 1-1998, qui định chênh lệch lãi suất được xóa bỏ, chỉ giũ lại qui định trần lãi suất cho vay.

Song hành với nới lỏng kiểm soát lãi suất, Ngân hàng Nhà nước liên tục điều chỉnh trần lãi suất cho vay theo hướng giảm cơ cấu trần và mức khống chế, đặc biệt trong hai năm 1998-1999. Lãi suất tái cấp vốn được điều chỉnh giảm để phù hợp với chỉ số lạm phát, quan hệ cung-cầu vốn trên thị trường và thực hiện giải pháp kích cầu của Chính phủ. Lãi suất tái cấp vốn năm 1997 là $1,1 \% /$ tháng, cắt xuống còn $0,7 \% /$ tháng từ ngày 4-9-1999. Các nghiệp vụ chiết khấu và tái chiết khấu giấy tờ có giá cho ngân hàng thương mại cũng được đưa vào sử dụng để bổ sung thêm công cự điều chỉnh lãi suất. Lãi suất tái chiết khâu được qui định ở mức thấp hơn $0,05 \%$ /tháng so với lãi suất tái cấp vốn. Từ tháng 7 2000, nghiệp vụ thị trường mở được áp dụng với lãi suất hình thành qua các phiên giao dịch (Anh và Thắng: 2002).

BẢNG 2: Mức lãi suất dương và lạm phát: 1996-2000

\begin{tabular}{|l|c|c|c|c|c|c|}
\hline & 1996 & 1997 & 1998 & 1999 & 2000 & $6 / 2008\left({ }^{*}\right)$ \\
\hline Mức lăi suất dương (\%) & 5,40 & 6,30 & 1,00 & 5,35 & 5,05 & $-6,00$ \\
\hline Lãi suất dương/lạm phát (\%) & 120 & 175 & 12 & 5350 & 6000 & -30 \\
\hline
\end{tabular}

Nguôn: Vụ Tài chính tiền tệ, Bộ Kế hoạch và Đầu tư, 2008. (*) Số ước lượng,

Cơ chế trên đã góp phần duy trì tăng trưởng kinh tế, kiểm soát lạm phát, ổn định sức mua của đồng Việt Nam trong tương quan với các đồng tiền trong khu vực vào lúc khủng hoảng tiền tệ xảy ra. Mức lãi suất dương được duy trì trong suốt 5 năm từ 1996 đến 2000. Nguyên nhân thiểu phát của những năm này được lý giải qua tỷ lệ cao giữa lãi suất dương và lạm phát (Lý: 2008). Ngoại trừ năm 1998 $(11,6 \%)$, thời điểm vừa xảy ra khủng hoảng tài chính khu vực, tỷ lệ này rất cao trong hai năm 1999 và 2000 - tới trên 5.000 và $6.000 \%$.

Cơ chế điều hành lãi suất với một mức cơ bản kèm biên độ dao động được Ngân hàng Nhà nước áp dụng kể từ tháng 8 . 2000 thay cho cơ chế lãi suất trần. Hai chỉ tiêu này được công bố chính thức định kỳ hàng tháng và điều chỉnh kịp thời trong trường hợp cần thiết. Đối với lãi suất cho vay bằng ngoại tệ, về cơ bản, các ngân hàng thương mại, tổ chức tín dụng được ấn định lãi suất cho vay trên cơ sở lãi suất thị trường quốc tế và cung cầu vốn trong nước của từng loại ngoại tệ. Đây là nền tảng cho việc xác định điểm cân bằng tỷ giá theo luật PPP, từ đó, hình thành một cơ chế tự điều chỉnh (Hoàng: 2003).

Đến tháng 5-2001, Ngân hàng Nhà nước từng bước chuyển sang áp dụng hình thức cho vay bằng ngoại tệ. Và kể từ tháng 52002 , cơ chế lãi suất thỏa thuận được áp dụng trong hoạt động tín dụng. 
Thống kê biện pháp điều chỉnh tiền tệ của Ngân hàng Nhà nước: 6 tháng đầu năm 2008

\begin{tabular}{|c|c|c|c|}
\hline Ngày & Công cụ & Nội dung điều chỉnh & Văn bản quí định \\
\hline $16-1-2008$ & Dự trữ bắt buộc & $\begin{array}{l}\text { Tăng từ } 10 \% \text { lên } 11 \% \text { với tiền gửi nội tệ và } \\
\text { ngoại tệ không kỳ hạn và dưới } 12 \text { tháng }\end{array}$ & 187/2008/QĐ-NHNN \\
\hline \multirow[t]{2}{*}{$30-1-2008$} & Lãi suất tái cấp vốn & $7,5 \% /$ năm (tăng $1 \%$ ) & \multirow{2}{*}{ 306/2008/QĐ-NHNN } \\
\hline & Lãi suất chiết khấu & $6 \%$ /năm (tăng $1,5 \%$ ) & \\
\hline $1-2-2008$ & $\begin{array}{l}\text { Tỷ lệ dư nợ cho vay } \\
\text { chứng khoán }\end{array}$ & $\begin{array}{c}\text { Tổng dư nợ cho vay, chiết khấu giây tờ có giá } \\
\text { để đâuu tư và kinh doanh chứng khoán khơng } \\
\text { vượt quá } 20 \% \text { vốn điều lệ của tổ chức tín } \\
\text { dụng }\end{array}$ & 03/2008/QĐ-NHNN \\
\hline $1-2-2008$ & Lãi suất cơ bản & $8,75 \%$ (tăng $0,5 \%$ ) & 305/2008/QĐ-NHNN \\
\hline $13-2-2008$ & Tín phiếu bắt buộc & $\begin{array}{l}\text { Phát hành } 20.300 \text { tỷ đồng tín phiếu bắt buộc, } \\
\text { lãi suất } 7,8 \% \text { /năm. Thực hiện } 17-3\end{array}$ & 346/QĐ-NHNN \\
\hline $16-5-2008$ & $\begin{array}{l}\text { Qui chế điều hành } \\
\text { lãi suất }\end{array}$ & $\begin{array}{c}\text { Tó chức tín dụng án định lãi suất kinh doanh } \\
\text { (lãi suất huy đợng, lãi suất cho vay) bằng } \\
\text { đống Việt Nam không vượt quá } 150 \% \text { lãi suất } \\
\text { cơ bản do Ngân hàng Nha nước Việt Nam } \\
\text { công bó }\end{array}$ & 16/2008/QĐ-NHNN \\
\hline $10-6-2008$ & Lãi suất cơ bản & 14/\%/năm & $1317 / \mathrm{Q} Đ-\mathrm{NHNN}$ \\
\hline \multirow[t]{2}{*}{$10-6-2008$} & Lãi suất tái cấp vốn & $15 \% /$ năm & \multirow{2}{*}{ 1316/QD-NHNN } \\
\hline & Lãi suất chiết khâu & $13 \% /$ năm & \\
\hline $26-6-2008$ & Tín phiếu bắt buộc & $\begin{array}{l}\text { Tăng lãi suất tín phiéu bắt buộc } \\
\text { (đã phát hành ngày } 17-3) \text { lên } 13 \% \text { /năm (+ } \\
5,5 \% \text { ) }\end{array}$ & 1435/QĐ-NHNN \\
\hline
\end{tabular}

Nguồn: Hệ thớng dữ liệu và phân tích tài chính www.asset.vn

Trước vận động bất lợi của TTCK và lạm phát tăng cao ngay từ đầu năm 2008, Ngân hàng Nhà nước thực thi chính sách thắt chặt tiền tệ, sử dụng đồng thời các công cự lãi suất và hoạt động thị trường mở. Từ giữa tháng một, dự trũ bắt buộc đã tăng thêm $1 \%$ với tiền gửi nội tệ và ngoại tệ từ không kỳ hạn tới dưới 12 tháng. Lãi suất tái cấp vốn gấp hai lần trong khoảng thời gian từ tháng một đến tháng sáu (15\%/năm: 10-6-2008). Mức lãi suất chiết khấu so với cuối năm 2007 cũng tăng thêm $8,5 \%$, ở mức $13 \% /$ năm từ ngày 10-6-2008. Tới giữa năm, Ngân hàng Nhà nước điều chỉnh lãi suất cơ bản lên $14 \% / n a ̆ m$. Với qui chế điều hành cho phép tổ chức tín dụng ấn định lãi suất kinh doanh không vượt quá $150 \%$ lãi suất cơ bản, trần lãi suất cho vay lên tới $21 \% / n a ̆ m$. Đặc điểm đáng chú ý nữa của thời gian này là lãi suất huy động ngắn hạn bằng (thậm chi cao hơn) lãi suất huy động dài hạn.

Nghiệp vụ thị trường mơ được thực hiện theo cả hai hướng mở rộng và thắt chật tiền tệ và không tạo nhiều tác động tới lãi suát. Trong tuần thứ ba của tháng 2-2008, Ngân hàng Nhà nước bổ sung 33.000 tỷ đồng vào lưu thông, nhưng các ngân hàng thương mại vẫn tiếp tục tăng lãi suát huy động tiền gưi $i^{9}$. Thông báo phát hành 20.300 tỷ đồng tín phiếu bắt buộc được đưa ra vào giữa tháng

9. Tại Ngan hàng thương mại cổ phấn Sài Gòn Hà Nợi (SHB), lâi suát huy đọng điểu chinh 3 lân chì trong vòng 10 ngày và tăng lên $12,5 \% / n a ̆ m$ với kỳ hạn 1 tháng. 
hai và thực hiện một tháng sau đó, trong bối cảnh mặt bằng lãi suất đang đi lên, rất khó xác định ảnh hưởng của nghiệp vụ này tới lãi suất. Trong tháng 6-2008, lãi suất huy động của các ngân hàng thương mại tiến gần tới trần lãi suất cho vay ${ }^{10}$. Hiệu lực không thật rõ của các nghiệp vụ thị trường mở vào thời kỳ lạm phát gia tăng cho phép đặt ra giả thiết tồn tại bẫy thanh khoản trong hệ thống tín dụng. Nếu đúng vậy, điều chỉnh tăng dần các công cự lãi suất là giải pháp hợp lý và sớm mang lại kết quả bình ổn thị trường tiền tệ.

Kết quả huy động thành công 2 tỷ đồng trái phiếu chính phủ kỳ hạn 2 năm với lãi suất $11 \%$ /năm vào cuối tháng sáu là một tín hiệu đáng mừng. Mặc dù khối lượng không lớn nhưng tín hiệu này gợi mở khả năng tiếp tục duy trì các chính sách tiền tệ-tài chính vĩ mô. Lưu ý rằng chỉ hai tuần trước đó, phiên đâu thầu hai loại trái phiếu chính phủ ngày 13-6-2008 với có kỳ hạn 2 và 3 năm đã không thu hút được bất kỳ thành viên nào tham gia. Trên thị trường, có tổ chức tài chính săn sàng chuyển nhượng lượng trái phiếu đang sở hữu với mức chiết khấu lên tới $40 \%$ mệnh giá nhưng vẫn không tìm được đối tác quan tâm.

So với giai đoạn 1997-1998, chính sách tiền tệ trong năm 2008 sử dụng nhiều công cụ hơn và cường độ điều chỉnh cũng cao hơn. Nhằm hỗ trợ các đơn vị kinh doanh vượt qua khó khăn trong bối cảnh khủng hoảng tài chính khu vực, chính sách tiền tệ được mơ rộng trong các năm từ 1997 đến 1999. Với mức lãi suất thực dương, các liệu pháp tiền tệ phát huy tác động ổn định kinh tế. Chi phí lãi vay cao kết hợp với tăng giá đầu vào tạo ra áp lực lớn với vận hành sản xuất kinh doanh trong năm 2008. Chấp nhận chi phí đầu vào tăng cao, hạn chế mở rộng tín dụng là những dấu hiệu cho thây hệ thống ngân hàng thương mại cũng gặp khó khăn với vấn đề thanh khoản. Điều này có thể là kết quả của những khoản tín dụng chất lượng thấp đã cung cấp trong thời gian trước, với tỷ lệ không nhỏ dành cho các dự án bất động sản và đầu tư tài chính. Hạn chế thống kê số liệu không cho phép nghiên cứu phân tích hiệu quả vận hành của khu vực ngân hàng.

\subsection{Tỷ giá hối doái}

Thu nhập của nền kinh tế, biểu hiện qua tốc độ tăng trưởng tác động gián tiếp tới tỷ giá thông qua cầu tiền. Khi các điều kiện vĩ mô khác không đổi, giá trị của đồng nội tệ tăng lên khi quốc gia có tốc độ tăng trưởng dương. Tăng trưởng dương làm mở rộng cầu tiền và với mức cung tiền ngoại sinh, áp lực dư cầu tiền chỉ được giải tỏa khi giá cả chung giảm xuống và tỷ giá tăng lên. (Mac Donald, 2000). Đóng góp của tỷ giá vào tăng trưởng có thể xác định qua mô hình MundellFleming:

$$
\mathrm{Y}_{\mathrm{t}}^{\mathrm{d}}=\alpha\left(\mathrm{s}_{\mathrm{t}}-\mathrm{p}_{\mathrm{t}}\right)-\beta \mathrm{r}_{\mathrm{t}}
$$

trong đó, $\mathrm{Y}_{\mathrm{t}}^{\mathrm{d}}$ là tổng cầu, $\mathrm{s}_{\mathrm{t}}$ là tỷ giá danh nghĩa, $p_{t}$ là mức giá cả chung và $r_{t}$ là kỳ vọng của lãi suất thực. Chính sách tiền tệ mở rộng trong mô hình này có khả năng mang lại mức tăng trưởng sản lượng lâu dài.

Khi đề cập tới các thành phần căn bản của tăng trưởng, mối quan tâm thường hướng vào giáo dục đào tạo, tiết kiệm và đầu tư, năng lực tạo ra hiểu biết mới về công nghệ và phương pháp tổ chức công việc. Khi này, tỷ giá thực trở thành công cụ tốt nhất có thể cân nhắc sử dụng nhằm tạo lập các điều kiện thuận lợi phát huy những nhân tố trên với khả năng đồng thời duy trì mức độ canh tranh của nền kinh tế và tránh các biến động quá đà (Eichngreen, 2008). Bài học trước tiên và trên hết tại các các nền kinh tế Đông Á có tốc độ tăng trưởng cao là luôn giữ tỷ giá ở mức cạnh tranh. Thực tế tại các quốc gia này cũng cho thấy, mức độ biến động cao của tỷ giá có ảnh hưởng tiêu cực tới xuất khẩu và đầu tư. Mặc dù chính sách tỷ giá không thể thay thế đội ngũ lao động có kỷ luật, tỷ lệ tiết kiệm cao, hay môi trường khuyến khích đầu tư, nhưng tỷ giá ổn định cổ vũ việc sắp xếp lại hiệu quả các nguồn lực sản xuất mang lại lợi ích ngay tức thì với năng suất lao động cao hơn.

10. Ngày 30-6-2008, Ngân hàng Kiên Long áp dụng lãi suất huy động tiền đồng $20 \%$ /năm cho khách hàng gửi tiền kỳ hạn 12 tháng. 
Ngân hàng Nhà nước Việt Nam áp dụng chế độ tỷ giá neo vào đồng đôla $\mathrm{Mỹ}$ với mức giảm giá từ $1 \%-2 \%$ mỗi năm (chủ yếu để xử lý chênh lệch lạm phát hàng năm giữa hai nền kinh tế) hướng tới mục tiêu ổn định tỷ giá hôi đoái. Trong hai năm 2006-2007, tỷ giá VND/USD có xu hướng tăng đều đặn. Trong vòng 24 tháng, tỷ giá bình quân ngân hàng tăng từ gần $15.900 \mathrm{VND/USD}$ lên xấp xỉ 16.200 VND/USD, tương đương 1,9\% - mức thuận lợi cho môi trường kinh tế vĩ mô. Bốn tháng đầu năm 2008, tỷ giá sụt giảm trên $150 \mathrm{VND} / \mathrm{USD}$, từ 16.100 trong tháng một xuống 15.959 vào tháng tư. Đảo chiều bất ngờ của tỷ giá trong hai tháng tiếp theo gây nhiều náo loạn trên thị trường ngoại hối. Trở lại mức 16.000 VND/USD trong tháng năm, tỷ giá tăng thêm 300 VND/USD ở tháng kế tiếp. Tốc độ tăng gần tới $2 \%$ trong một tháng.

Trên thị trường tự do ${ }^{11}$, dấu hiệu tăng tỷ giá bắt đầu xuất hiện từ cuôî tháng 3-2008 khi chênh lệch với tỷ giá chính thức (do hệ thống ngân hàng công bố theo điều chỉnh và giám sát của Ngân hàng Nhà nước) từ 150250 VND/USD. Ngày 18-3-2008, phương án giao dịch với tỷ giá thỏa thuận tại các ngân hàng thương mại đã được Vụ Quản lý ngoại hối cân nhắc.

\section{HÌNH 4: Biến động tỷ giá: 2006-2008}

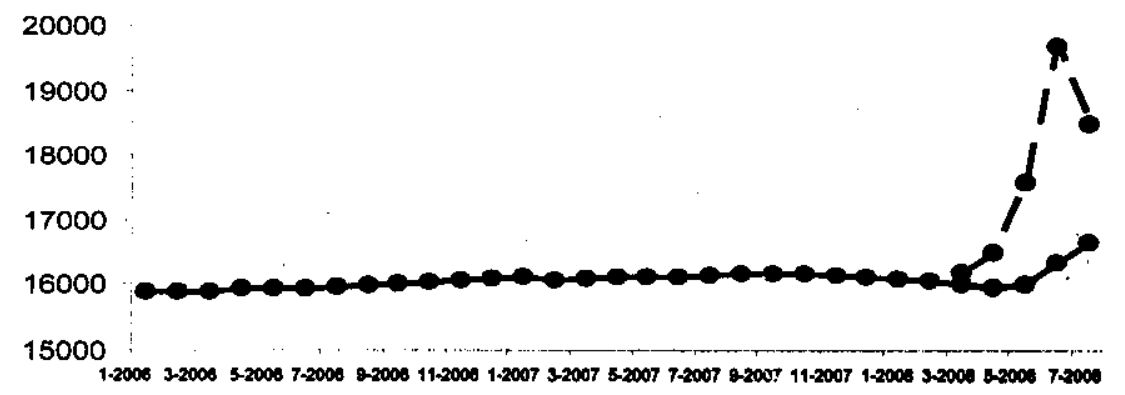

$\longrightarrow$ Bình quân ngân hàng $\longrightarrow-$ Tụ do

Nguồn: www.asset.vn. Đơn vị: VND/USD

Không chịu sự kiểm soát của một mức cơ bản hay biên độ dao động, tỷ giá áp dụng trên thị trường tự do liên tục tăng lên. Trong tháng năm, tỷ giá đã tới gần sát 18.000 VND/USD. Sang tháng sáu, có thời điểm đôla Mỹ bán ra với giá 19.700 VND/USD trước khi lùi dần về mức $18.000 \mathrm{VND} / \mathrm{USD}$ vào cuối tháng. Mức thay đổi lớn trong khoảng thời gian ngắn tạo nên trạng thái khan hiếm và khó khăn trong giao dịch chuyển đổi từ đồng Việt Nam sang đôla Mỹ. Tại các địa điểm giao dịch tư nhân, tỷ giá được xác định theo từng lần giao dịch. Mức chênh lệch giữa mua vào và bán ra tương đối lớn, từ 200 đến 300 đồng với một đôla Mỹ. Cá biệt, khảo sát vào ngày 19-6-2008 ghi nhận khoảng cách này lên tới 1.000 đồng.

Trong nỗ lực bình ổn thị trường, Ngân hàng Nhà nước đã điều chỉnh tỷ giá bình quân liên ngân hàng tăng 2\%, từ 16.139 VND/USD lên 16.461 VND/USD vào ngày 11-6-2008. Trước đ6, ngày $6 \cdot 6 \cdot 2008$, biện pháp giám sát hành chính chặt chẽ được áp dụng nhằm chấm dứt các hoạt động trao đổi tự do đồng Việt Nam và đôla Mỹ - không tuân theo tỷ giá qui định và biên độ dao động $\pm 1 \%$. Trước áp lực tỷ giá tăng cao, ngày 27-6-2008, Thống đốc Ngân hàng Nhà nước đồng ý nới rộng biên độ giao dịch lên múc $\pm 2 \%$.

11. Thị trường chợ đen, tự do bao gốm: các điểm giao dịch ngoại tệ tư nhan, cửa hàng vàng bạc... Theo so liệu của NHNN, tính tơi tháng 6-2008, cả nước có 3.591 bàn thu đổi ngoại tệ, trong đó, có 2.294 bàn thu đó̉i trực tiếp của các tổ chức tín dụng. Trên địa bàn Hà Nội có 921 bàn, trong đó 687 bàn của tố chức tín dụng. Tren địa bàn TP. Hó Chí Minh có 1.219 bàn, trong đó 645 bàn của tổ chức tín dụng. 
Thời kỳ 1997-1998 cũng ghi nhận ba lần điều chỉnh tỷ giá vào tháng 7.1997 (bình quân 11.690 VND/USD), tháng 2-1998 (bình quân 12.664 VND/USD) và tháng 8-1998 (bình quân $13.715 \mathrm{VND} / \mathrm{USD}$ ) với kết quả tỷ giá VND/USD giảm khoảng $17 \%$ (Ngân hàng Thế giới: 1998 và thống kê tỷ giá của $\mathrm{ASSET}^{12}$ ). Mặc dù cùng làm giảm giá đồng Việt Nam nhưng về bản chất, mục tiêu của các điều chỉnh này hoàn toàn khác biệt. Giảm giá đồng Việt Nam trong giai đoạn khủng hoảng tài chính-tiền tệ Châu Á hướng tới việc tăng cường năng lực cạnh tranh cho hàng hóa xuất khẩu của Việt Nam trước các đối thủ cạnh tranh trong khu vực (Philipin, Thái Lan, Malaixia, hay Hàn Quốc). Các động thái của năm 2008 ưu tiên việc củng cố sự tin tưởng của cộng đồng doanh nghiệp và đa số người dân vào mức độ bền vững của hệ thống tín dụng-ngân hàng, giải quyết nhu cầu thanh toán bằng ngoại tệ của nền kinh tế.

\section{BẢNG 3: Thống kê biến động tỷ giá VND/USD}

\begin{tabular}{||l|c|c|c|c||}
\hline \multicolumn{1}{|c|}{ Ngày } & \multicolumn{2}{|c|}{$\begin{array}{c}\text { Ngân hàng (thỏa } \\
\text { thuận) }\end{array}$} & \multicolumn{2}{c||}{ Chợ đen } \\
\hline & Mua vào & Bán ra & Mua vào & Bán ra \\
\hline $28-3-2008$ & & & 16165 & 16260 \\
\hline $25-5-2008$ & & & & 17150 \\
\hline $27-5-2008$ (sáng) & & & & 17200 \\
\hline $27-5-2008$ (trưa) & & & 17300 & 17600 \\
\hline $4-6-2008$ (sáng) & & & & 17600 \\
\hline $4-6-2008$ (trưa) & & & & 17700 \\
\hline $4-6-2008$ (chiều) & & & & 17800 \\
\hline $4-6-2008$ (tói) & & & 17800 & 18000 \\
\hline $6-6-2008$ & & & Kiểm soát chật giao dịch chọ đen \\
\hline $12-6-2008$ & & 17600 & & 18000 \\
\hline $16-6-2008$ & & & 17700 & 18000 \\
\hline $19-6-2008$ & & 19500 & 18700 & 19700 \\
\hline $20-6-2008$ & 17500 & 18500 & 18250 & \\
\hline $24-6-2008$ & & 18500 & & \\
\hline
\end{tabular}

Nguồn: Tổng hợp số liệu tại www.ASSET.vn

\subsection{Dòng vốn nước ngoài}

Dòng vốn nước ngoài vào Việt Nam được thể hiện trên cán cân thanh toán. Nỗ lực mở cửa nền kinh tế đã mang lại những kết quả đáng khích lệ trong hoạt động ngoại thương với kim ngạch xuất nhập khẩu liên tục tăng cao. Năm 2006 đã có 9 mặt hàng đạt doanh thu xuất khẩu trên 1 tỷ USD. Tuy vậy, nhập khẩu luôn cao hơn xuất khẩu và xu hướng gia tăng nhập siêu chưa có dâu hiệu điều chỉnh. Nguồn hình thành dự trũ ngoại hối chủ đạo là các dòng vốn đầu tư trực tiếp và gián tiếp tăng mạnh trong vài ba năm trở lại đây.

12. Hệ thống dữ liệu và phân tích tài chính www.asset.vn 


\begin{tabular}{|c|c|c|c|c|c|}
\hline & 2004 & 2005 & 2006 & 2007 & $2007(*)$ \\
\hline Tài khoản vãng lai & $-1,6$ & 0,2 & 0,2 & $-6,4$ & $-9,0$ \\
\hline Số dư hàng hóa và dịch vụ & $-3,2$ & $-2,0$ & $-2,8$ & $-9,0$ & $-12,6$ \\
\hline Số dư thu nhập từ đầu tư & $-0,9$ & $-1,2$ & $-1,4$ & $-1,6$ & $-2,3$ \\
\hline Chuyển tiền cá nhân ròng & 2,5 & 3,4 & 4,4 & 4,2 & 5,9 \\
\hline Tài khoản vốn & 2,6 & 1,9 & 4,1 & 15,2 & 21,4 \\
\hline FDI ròng & 1,9 & 2,0 & 2,4 & 4,0 & 5,6 \\
\hline Các dòng tài chính khác (ròng) & 0,7 & $-0,1$ & 1,7 & 11,2 & 15,8 \\
\hline Thay đổi dự trữ ngoại tệ & $+1,0$ & $+2,1$ & $+4,3$ & $+8,8$ & $+12,4$ \\
\hline
\end{tabular}

Nguồn: Tông hợp IMF, www.asset.vn (*) Tính toán \% với GDP

Số dư tài khoản vốn năm 2006 là 4,1 tỷ USD, gấp hơn hai lần con số 1,9 tỷ của năm liền trước đó. Năm 2007 mới thực sự ấn tượng, vốn đầu tư trực tiếp nước ngoài vào Việt Nam có giá trị 4 tỷ USD (gấp gần 2 lần con số của năm 2006) và các dòng tài chính khác (bao gồm cả $\mathrm{ODA}$, vốn vay, và đầu tư gián tiếp) có giá trị kỷ lục là 11,2 tỷ USD (năm 2006 là 1,7 tỷ USD). Đóng góp từ nguồn kiều hối vào dự trữ ngoại tệ quốc gia cũng đang tăng lên với trung bình 4 tỷ USD hàng năm.

Trong năm 2007, thâm hụt thương mại tăng gấp 3 lần so với năm trước, tương đương gần $13 \%$ GDP. Và khoảng $40 \%$ dòng vốn tài chính dổ vào Việt Nam (hơn $21 \%$ GDP) đã được sư dụng để bù đắp phần thâm hụt trên tài khoản vãng lai. Trong hai năm trước đó,
2005 và 2006, gần như toàn bộ tài khoản vốn được chuyển thành dự trữ ngoại tệ quốc gia. Khi số dư của tài khoản vốn tăng khoảng hai lần từ 1,9 lên 4,1 tỷ USD, thay đổi dự trũ ngoại hối cũng tăng tương ứng từ 2,1 lên 4,3 tỷ USD. Con số 8,8 tỷ USD chênh lệch giữa tài khoản vốn và vãng lai được Ngân hàng Nhà nước Việt Nam mua vào và bổ sung nguồn dự trũ ngoại hối.

Trong 5 tháng đầu năm 2008, giá trị hàng hóa nhập khẩu vào Việt Nam tăng cao, trên $67 \%$ so với cùng kỳ năm 2007. Dù xuất khẩu cũng tăng $27 \%$ so với cùng kỳ năm trước và đạt giá trị 23,4 tỷ USD, mức thâm hụt thương mại của của nửa đầu năm 2008 vẫn là con số lớn: 14,4 tỷ USD. $^{13}$ Đây là về mức cầu ngoại hố.

\section{BẢNG 5: Đầu tư trực tiếp nước ngoài 1996-2000}

\begin{tabular}{|c|c|c|c|c|c|c|}
\hline & \multirow{4}{*}{ Số dự } & \multicolumn{4}{|c|}{ Vớn đăng ký (triệu USD) (*) } & \multirow{4}{*}{$\begin{array}{c}\text { Tởng só vớn thực hiẹn } \\
\text { (triệu USD) }\end{array}$} \\
\hline & & \multirow{3}{*}{$\begin{array}{c}\text { Tổng } \\
\text { só }\end{array}$} & \multicolumn{3}{|c|}{ Trong đo: Vốn pháp định } & \\
\hline & & & \multirow{2}{*}{$\begin{array}{c}\text { Tổng } \\
\text { số }\end{array}$} & \multicolumn{2}{|c|}{ Chia ra } & \\
\hline & & & & $\begin{array}{c}\text { Nước } \\
\text { ngoài góp }\end{array}$ & $\begin{array}{l}\text { Việt Nam } \\
\text { góp }\end{array}$ & \\
\hline Tổng số & 8266 & 78248.2 & 34945.4 & 29613.7 & 5331.7 & 37271.7 \\
\hline $1996-2000$ & 1724 & 26259.0 & 10921.8 & 8714.5 & 2207.3 & 12944.8 \\
\hline 1996 & 372 & 10164.1 & 3511.4 & 2906.3 & 605.1 & 2714.0 \\
\hline 1997 & 349 & 5590.7 & 2649.1 & 2046.0 & 603.1 & 3115.0 \\
\hline 1998 & 285 & 5099.9 & 2474.2 & 1939.9 & 534.3 & 2367.4 \\
\hline 1999 & 327 & 2565.4 & 975.1 & 870.5 & 104.6 & 2334.9 \\
\hline 2000 & 391 & 2838.9 & 1312.0 & 951.8 & 360.2 & 2413.5 \\
\hline
\end{tabular}

Nguồn: Tởng cục Thống kê, 2008.

13. Só liệu thớng ke 5 tháng đầu năm 2008 của Tổng cục Thớng kê. 
Xét về mặt cung ngoại hối, các hình thức FDI, ODA, vốn đầu tư gián tiếp vào các thị trường tài sản cùng nhau hình thành dòng vốn nước ngoài chảy vào Việt Nam. Tuy vậy, các loại hình này có sự khác nhau cơ bản về mức độ rủi ro. Các nguồn vốn FDI và ODA có rất ít khả năng đột ngột đổi hướng. Vốn đầu tư gián tiếp vào các thị trường cổ phần và nợ thì ngược lại, vô cùng dễ thay đổi. Trong những năm gần đây, vốn FDI ròng của Việt Nam dao dộng quanh mức 2 tỷ USD. Năm 2007 ghi nhận mức tăng đột biến lượng vốn đầu tư trực tiếp, có lẽ đây là một phản ứng tích cực của việc gia nhập WTO vào đầu năm. Nguồn ODA tương đối ổn định ở mức 1,3 tỷ USD mỗi năm. Ngay từ nửa cuối năm 2006, nguồn vốn đầu tư gián tiếp đã được "khích lệ" chuyển vào TTCK Việt Nam khi chỉ số thị trường tăng lên gấp đôi. Trong năm 2007, có tới 10 tỷ USD đầu tư gián tiếp vào Việt Nam, tương đương $15 \%$ GDP.

Suy giảm trên TTCK kể từ đầu năm 2008 , lợi tức kỳ vọng cao từ trái phiếu chính phủ và dự báo đồng Việt Nam tăng giá là tín hiệu dẫn đường cho một dòng vốn lớn dồn cho hoạt động đầu cơ tỷ giá vào thời điểm tháng 32008. Hành động này được đại diện một quỹ đầu tư nước ngoài tại Việt Nam lý giải, các nhà đầu tư nước ngoài có thể sử dụng đồng đôla $M y ̃$ với mức lãi suất phổ biến xấp xỉ $6 \%$ để đầu tư vào một đồng tiền có xu hướng tăng giá rõ ràng. Số liệu thống kê chưa chính thức ước lượng, các nhà đầu tư nước ngoài đã thực hiện tới $95 \%$ tổng giá trị giao dịch trên cả thị trường nợ chính phủ sơ cấp và thứ cấp. Trong tháng ba, giá trị giao dịch bình quân mỗi ngày ước đạt 40 triệu USD, gấp hai lần so với cùng thời điểm năm 2007.

Dòng vốn đầu tư trực tiếp nước ngoài tiếp tục xu thế gia tăng và hiện diện mạnh mẽ của các khoản đầu tư tài chính gián tiếp là điểm khác biệt nổi trội giữa hai giai đoạn 2007-2008 và 1997-1998. Khủng hoảng tài chính khu vực năm 1997 ngay lập tức tấn công vào hệ thống tín dụng-ngân hàng và tạo thành làn sóng rút vốn đầu tư ra khỏi Châu Á. Những nhà đầu tư lớn vào Việt Nam đến từ các quốc gia láng giềng trong khu vực và họ cũng tức thì lâm vào trạng thái thiếu tiền mặt. Một vài nhà đầu tư tìm kiếm lợi nhuận ngắn hạn xuất hiện và đã vận hành khá tốt tại Việt Nam. Tuy nhiên, những rào cản hạn chế khả năng chuyển đổi từ tiền đồng sang ngoại tệ và cơ chế hành chính cồng kềnh tại Việt Nam đã tạo lợi thế cạnh tranh cho các nền kinh tế Thái Lan và Hàn Quốc. Số lượng dự án đăng ký mới giảm sút từ 349 năm 1997 xuống còn 285 và 327 trong các năm 1998 và 1999 . Nhưng qui mô vốn đầu tư mới thực sự suy giảm. Năm 1997 có 5,6 tỷ USD FDI đăng ký vào Việt Nam. Con số này chỉ còn 5 tỷ USD trong năm 1998, trong 2 năm tiếp theo, lượng vốn đăng ký chỉ còn khoảng $50 \%$ của năm 1997. Số vốn thực hiện trong 3 năm liên tiếp từ năm 1998-2000 dừng ở mức trên 2,3 tỷ USD mỗi năm.

\section{Những luận điểm cốt lõi và vấn đề cần tiếp tục nghiên cứu làm rõ}

Biến cố kinh tế của những năm 1997-1998 và 2007-2008 cùng được ghi nhận với các tín hiệu suy giảm tăng trưởng kinh tế, đầu tư và tiêu dùng thu hẹp, kinh doanh khó khăn, tốc độ chậm, cơ hội việc làm sụt giảm, đời sống người dân khó khăn... Tuy vậy, xem xét các vấn đề nền tảng kinh tế vĩ mô cho thấy có những khác biệt về nguồn gốc, mức độ phức tạp và tác động của các giải pháp vĩ mô giữa hai giai doạn.

Khủng hoảng tài chính tiền tệ Đông Á năm 1997 là nguyên nhân trực tiếp khiến các đối tác đến từ những quốc gia trong khu vực từ bỏ hoặc tạm dừng triển khai hoạt động đầu tư tại Việt Nam. Mất đi nguồn lực đóng góp 5\%.10\% GDP, nền kinh tế khó tránh khỏi tình trạng suy thoái. Với nhiều vấn đề nảy sinh đồng thời như tụt giảm trên TTCK, năng lực thanh khoản kém của hệ thống ngân hàng thương mại, tiền đồng Việt Nam mất giá nhanh trên thị trường ngoại hối và mức giá cả tăng cao..., rất khó xác định đâu là nguyên nhân căn bản của những khó khăn kinh tế hiện rõ kể từ tháng 3-2008. 


\subsection{Khác biệt đặc trưng 1997-1998 và 2007-2008}

Từng giai đoạn phát triển kinh tế có các đặc trưng riêng. Liệu pháp vĩ mô được triển khai để khắc phục khủng hoảng và phục hồi tăng trưởng bởi vậy có nhiều khác biệt. Tình trạng giảm phát và mức lãi suất dương trong 5 năm liên tiếp tạo điều kiện để Chính phủ theo đuổi mở rộng chính sách tiền tệ. Lãi suất được cắt giảm nhằm khuyến khích đầu tư và tiêu dùng. Tiền đồng Việt Nam được giảm giá đều đặn tới $17 \%$ trong 12 tháng nhằm hỗ trợ xuất khẩu, tăng năng lực cạnh tranh cho hàng hóa nội địa và tính hấp dẫn của các cơ hội kinh doanh tại Việt Nam.

So sánh đặc trưng kinh tế vĩ mô hai giai đọan 1997-1998 và 2007-2008

\begin{tabular}{|c|c|c|}
\hline \multirow{2}{*}{ Tiêu chí } & \multicolumn{2}{|c|}{ Nội dung } \\
\hline & 1997-1998 & $2007-2008$ \\
\hline Tăng trưởng & $\begin{array}{l}\text { 1992-1997: } 9 \% \text { (bình quân) } \\
\text { 1998-2000: } 7-8 \%\end{array}$ & $\begin{array}{l}\text { 2002-2007: 7,9\% (bình quân) } \\
\text { 6/2008: } 6,5 \%\end{array}$ \\
\hline Lạm phát & $\begin{array}{l}\text { 1996-2000: giảm phát. } \\
\text { Lãi suất dương: 4,6\%/năm (1996-2000) }\end{array}$ & $\begin{array}{l}\text { Tăng liên tục. } 2007: 12,6 \% \text {. } \\
5 \text { tháng 2008: tăng giá } 19 \%\end{array}$ \\
\hline Lãi suất & $\begin{array}{l}\text { Giảm lãi suất chiết khâu: thấp hơn } 0,05 \% \text { /tháng } \\
\text { so với lãi suất tái cấp vốn } \\
\text { Giảm suất tái cấp vốn: }-0,4 \% \text {; ngày } 4-9-1999 \\
\text { Chênh lệch lãi suất kinh doanh: } 4,2 \% / n a ̉ m ~\end{array}$ & $\begin{array}{l}\text { Tãng lãi suất tái cấp vốn: +1\%; ngày 30-1-2008 } \\
\text { Tăng lãi suất chiết khâu: + 1,5\%; ngày 30-1- } \\
2008 \\
\text { Tãng lãi suất cơ bản: 14\%/năm; ngày 10-6-2008 } \\
\text { Lãi suất kinh doanh không.vượt quá 150\% lãi } \\
\text { suất cơ bản }\end{array}$ \\
\hline Tỷ giá hôi đoái & $\begin{array}{l}\text { Đồng Việt Nam giảm giá với tốc độ đều } \\
17 \% \text { trong } 12 \text { tháng với } 3 \text { lần điều chỉnh }\end{array}$ & $\begin{array}{l}\text { Đồng Việt Nam tăng giá trong 2006-2007 và } \\
\text { giảm giá đột ngột từ đầu năm 2008. Chênh lệch } \\
\text { giữa thị trường chính thức và tự do có lúc tới } \\
20 \% \text {. }\end{array}$ \\
\hline $\begin{array}{l}\text { Đầu tư nước } \\
\text { ngoài }\end{array}$ & $\begin{array}{l}\text { FDI có chiếm tỷ trọng tuyệt đối. } \\
\text { Dòng vốn nước ngoài trì trệ và sụt giảm. Vốn thực } \\
\text { hiện năm } 1998 \text { giăm } 24 \% \text { so với } 1997\end{array}$ & $\begin{array}{l}\text { Dòng vốn nước ngoài tăng mạnh. } \\
\text { Đâu tư gián tiếp chiếm ưu thế: gấp gân } 3 \text { lần FDI } \\
\text { vào năm } 2007 \text {. }\end{array}$ \\
\hline TTCK & Chưa có & $\begin{array}{l}\text { Qui mô, lực lượng tham gia đọng đảo. } \\
\text { Liên thông với thị trường tiền tệ, bất đợng sản } \\
\text { (Hoàng, 2008) } \\
\text { Ẩnh hưởng kinh tế-xã hội rộng khắp }\end{array}$ \\
\hline $\begin{array}{l}\text { Mức độ hội } \\
\text { nhập }\end{array}$ & $\begin{array}{l}\text { Khu vực: ASEAN (1995), AFTA (1996), APEC } \\
\text { (1998) }\end{array}$ & Toàn cầu: US-BTA (2001), WTO (2007) \\
\hline
\end{tabular}

Ngược lại, chỉ số giá tiêu dùng không ngừng tăng lên gây áp lực cho Ngân hàng Nhà nước. Theo đuổi chính sách tiền tệ thắt chặt, gần như toàn bộ công cụ điều chỉnh tiền tệ đã được huy động. Lãi suất tái cấp vốn, lãi suất chiết khấu, lãi suất cơ bản, biên độ lãi suất kinh doanh cùng được điều chỉnh tăng. Các nghiệp vụ thị trường mở cũng được áp dụng trong điều chỉnh cung tiền nhưng không mang lại k:ŝ́t quả như trông đợi.

Khủng hoảng tài chính Châu Á 1997 gây gián đoạn dòng vốn đầu tư nước ngoài, hàng loạt dự án đầu tư chậm tiến độ, hoặc buộc phải dừng không thời hạn. Tuy vậy, phần đông đối tác Việt Nam tham gia các dự án có vốn đầu tư nước ngoài đều đóng góp bằng đất đai, nhà xưởng, hay đội ngũ nhân lực. Do vậy, ngưng trệ các dự án đầu tư mới chỉ đồng nghĩa với việc các tài sản này chưa tham gia vào quá trình tạo ra giá trị mới chứ không tạo áp lực tài chính đáng kể nào lên cỗ máy kinh doanh.

TTCK sụt giảm mạnh vào đầu năm 2008 khép lại cánh cửa huy động vốn quan trọng. Nhiều doanh nghiệp Việt Nam lâm vào tình trạng khó khăn chi trả do lượng tích lũy và 
huy động trước đó hầu như đã đưa toàn bộ vào các dự án triển khai dang dở. Hơn thế, nhiều quyết định tiêu dùng và đầu tư đã được thực hiện ngay trong quá trình lập kế hoạch kinh doanh và huy động vốn mới- lúc này đã trở nên không khả thi. Doanh nghiệp chỉ còn kênh tín dụng của hệ thống ngân hàng để giải quyết nhu cầu chi trả trước mắt. Đây là nhiệm vụ khó khăn bởi chính hệ thống ngân hàng cũng sa lầy với các khoản vay cầm cố chứng khoán, đầu tư bất động sản "lt làm suy yếu năng lực thanh khoản của hệ thống tín dụng. Quý II/2008 chứng kiến cuộc đua lãi suất huy động tiền gửi giữa các ngân hàng thương mại.

Qui mô của doanh nghiệp tại một thập kỷ trước cũng còn rất khiêm tốn, nhờ thế mà xoay trở nhanh nhẹn trước khó khăn. Kết quả khảo sát 12 doanh nghiệp vừa và nhỏ có vị thế đứng đầu trong mỗi ngành cho thây, nhu cầu vốn và qui mô tài sản dừng ở mức một vài triệu USD (Hoàng: 1997). Bình quân nhu cầu vốn là 1,3 triệu USD, qui mô tài sản là 2,1 triệu USD. Sau 10 năm, những doanh nghiệp có tài sản hàng trăm tỷ đồng, dự án đầu tư nhiều triệu đôla $\mathrm{Mỹ}$ đã không còn khiến công chúng ngạc nghiên. Điều gì đã tạo nên sự khác biệt này? Với hình thể lực lưỡng hơn nhiều lần, sức mạnh cạnh tranh và năng lực tạo thêm giá trị liệu đã tăng nên tương xứng? (Hoàng: 2007, tr 42-43)

BẢNG 6: Khảo sát qui mô tài sản và nhu cầu vốn doanh nghiệp nhỏ và vừa, 1997

\begin{tabular}{|l|c|c|}
\hline Ngành kinh doanh & Tài sản & Nhu câuu vốn \\
\hline Điện gia dụng & 1,1 & 0,4 \\
\hline Nhựa & 2 & 1 \\
\hline Trang sức & 4 & 1,5 \\
\hline Quạt & 1,2 & 1,2 \\
\hline Gỗ & 5 & 4 \\
\hline Sơn & 0,5 & 0,4 \\
\hline Hải sản & 0,8 & 0,8 \\
\hline Bình quân & 2,1 & 1,3 \\
\hline
\end{tabular}

Nguồn: Vietnam Investment Review, 1997. Đơn vị tính: triệu USD

\subsection{Biến cố kinh tế 2007-2008 phức tap hon}

Tính phức tạp của biến cố kinh tế năm 2007-2008 càng tăng lên khi hội nhập kinh tế quốc tế của Việt Nam từ cấp khu vực lên toàn cầu. Khủng hoảng nợ dưới chuẩn bất động sản tại Hoa Kỳ gửi một tín hiệu từ xa tới Việt Nam nhưng các cam kết tự do hóa hoạt động thương mại, dịch vụ, đầu tư thì rất cư thể và trực tiếp. Không chỉ tăng lên về số lượng các đối tượng tham gia hoạt động kinh tế Việt Nam, các tổ chức và nhóm cá nhân cũng có hình thức đa dạng và phương thức tương tác tinh vi hơn. Xuất hiện những khái niệm mới trong hệ thống kinh tế như công ty đại chúng, tập đoàn kinh tế, đầu tư tài chính, mua bán-sáp nhập. Quá trình hội nhập quốc tế cũng góp phần nâng cao nhận thức về các khái niệm phát triển thương hiệu, bảo hộ quyền sở hữu trí tuệ, truyền thông kinh doanh, quản trị xung đột trong công ty... Tính phức tạp cao cũng là một thách thức cho những nỗ lực đưa nền kinh tế trở lại chu kỳ ổn định và phát triển.

\subsection{Quan sát cẩn trọng}

Cỗ máy kinh tế thế giới đang chuyển động với vận tốc cao. Các tác nhân và chỉ số của hệ thống kinh tế Việt Nam cũng vận động liên tục. Quan sát cẩn trọng và tập trung vào những điểm cốt yếu của hệ thống kinh tế là cần thiết.

Giai đoạn 2005-2007, Trung Quốc - nền kinh tế tăng trưởng bậc nhất thế giới với nhiều tính tương đồng về thể chế, cũng từng đối mặt với những vấn đề kinh tế vĩ mô như đồng nội tệ giảm giá, lạm phát tăng cao..., nhưng đã xử lý được nhờ các biện pháp cứng rắn (loại bỏ những ngân hàng nhỏ, hoạt động kém hiệu quả tiềm lực tài chính mạnh của Chính phủ). Cũng cần lưu

14. www.ASSET.vn (9/3/2008)- Khảo sát nhanh hệ thống ngân hàng thương mại ghi nhận tỉ lệ dư nợ bất động sản trên tổng dư nợ dao động ở mức từ $20 \%-40 \%$. Theo khuyến cáo của Ngân hàng Nhà nước, các ngân hàng thương mại có tỷ lệ cấp tín dụng bất động sản cao khi vượt mức $30 \%$ tổng dư nợ. 
ý rằng Trung Quốc đã vượt lên rất nhanh kể từ khi từ bỏ hệ thống kinh tế quản lý tập trung, tiến gần phương thức điều hành vĩ mô của các nền kinh tế phát triển.

Trong thời gian sắp tới, nền kinh tế Việt Nam tiếp tục đối diện thực tế lãi suất tăng cao, chi phí đầu vào đắt đỏ, và với năng lực điều hành, qui hoạch sử dụng nguồn lực còn hạn chế, chúng ta sẽ buộc phải chấp nhận sự biến mất của những đơn vị kinh doanh kém hiệu quả trong đời sống kinh tế. Một bộ luật phá sản tốt phải vừa giúp đẩy nhanh quá trình thanh lọc, vừa tạo điều kiện thuận lợi cho quá trình bắt đầu một hoạt động kinh doanh mới. Định kiến xã hội với tầng lớp doanh nhân nói chung, và các doanh nhân gặp thất bại nói riêng, cần được xóa bỏ. Cộng đồng cổ vũ các ý tưởng kinh doanh đúng pháp luật, tạo ra giá trị cho xã hội và phù hợp với lợi ích chung của cộng đồng.

\subsection{Siêu quyền lực của hệ thống ngân \\ hàng}

Lịch sử kinh tế Việt Nam ghi nhận hệ thống ngân hàng luôn nắm giũ siêu quyền lực. Ngay cả khi TTCK đã ra đời và hoạt động sôi nổi, vị thế này vẫn không thay đổi. Nguồn tín dụng từ hệ thống ngân hàng là một động lực quan trọng thúc đẩy tăng trưởng của TTCK. Các chính sách thắt chặt nguồn tín dụng cho hoạt động đầu tư và kinh doanh chứng khoán luôn nhận được phản đối mạnh mẽ từ mọi thành phần của thị trường này. Sức khỏe của hệ thống ngân hàng, do vậy, càng trở nên quan trọng bởi nó tác động trực tiếp tới sức khỏe tài chính của cộng đồng doanh nghiệp.

Giám sát chặt chẽ hoạt động và hiệu quả vận hành của hệ thống tín dụng-ngân hàng cần được ưu tiên hàng đầu. Tăng cường năng lực quản trị rủi ro, xây dựng hệ thống xếp hạng tín dụng, ứng dụng công nghệ thông tin cốt lõi tiên tiến... hướng tới vận hành tối ưu tại các ngân hàng là những khái niệm thường được cồ vũ. Tuy vậy, trong bối cảnh hiện tại, nhiệm vụ trước tiên và trên hết của các ngân hàng là tồn tại và vượt qua thời kỳ khó khăn tín dụng. Theo dõi sát sao từ các cơ quan quản lý, các bên có quyền lợi liên quan giúp các ngân hàng kịp thời điều chỉnh, đồng thời, hạn chế khả năng lây truyền tác động khi buộc phải loại bỏ một mắt xích của dây chuyền.

3.5. Vai trò của thông tin và truyền thông

Hạ tầng công nghệ và truyền thông của năm 2007-2008 vượt xa thời kỳ 1997-1998. Bên cạnh các phương tiện truyền thống như báo, truyền hình, truyền thanh, ứng dụng phổ biến của internet và hình thức truyền thông đa phương tiện có khả năng cung cấp lượng thông tin khổng lồ với hiệu quả chi phí cao tới công chúng. Nhu cầu hiểu biết cưa công chúng cũng tăng lên rõ rệt. Số lượng vấn đề quan tâm không dừng lại ở các đại lượng vĩ mô truyền thống như tăng trưởng, lãi suất, lạm phát, giá cả, tỷ giá, việc làm, đầu tư, cán cân thương mại mà bổ sung thêm các khái niệm về quản trị và điều hành, qui hoạch chiến lược, phát triển thương hiệu, xây dựng cơ cấu vốn tối ưu, quạan hệ nhà đầu tư... Chất lượng thông tin rất được coi trọng khi lượng thông tin trở nên quá lớn. Chúng tôi chia sẻ quan điểm trao đổi với GS. Riedel (Johns Hopkins) rằng "Thiếu nghiên cứu và bất đôi xứng thông tin là một thứ thuế có hại, người trả là phần lớn cư dân, nhưng người nhận không phải là ngân sách chính phủ mà là túi tiền nhà đầu cơ." Đảm bảo khả năng tiếp cận công bằng, tính đầy đủ và khoa học của thông tin là yêu cầu và nhiệm vụ của hệ thống truyền thông và giới báo chí.

Thông tin và hiểu biết tốt chỉ có thể được tạo ra từ năng lực nghiên cứu và dự báo các vấn đề kinh tế. Trong hệ thống kinh tế-xã hội Việt Nam, ý kiến phát ngôn từ những cơ quan quản lý đầu ngành luôn là tín hiệu quan trọng bậc nhất đối với thị trường. Tuy vậy, khả năng cung cấp các phân tích và nhận định thuyết phục, đảm bảo yếu tố khoa học ở những đầu mối này hiện nay còn yếu. Đây là điểm khắc phục càng sớm càng tốt.

\subsection{Xây dựng năng lực nghiên cưu và dú báo}

Tại các nền kinh tế phát triển, những cơ quan quản lý cấp cao của các thị trường như 
Ngân hàng Trung ương, Ủy ban Chứng khoán xác định ưu tiên cao nhất cho chức năng nghiên cứu và cung cấp thông tin. Đang trong giai đoạn chuyển đổi từ cơ chế quản lý tập trung sang cơ chế thị trường, cơ quan quản lý của Việt Nam vẫn đặt nặng nhiệm vụ tác nghiệp bằng mệnh lệnh và giám sát quá trình triển khai. Cách làm này tốn nhiều nguồn lực và không hiệu quả. Trên thị trường, các tổ chức và nhóm dân cư tương tác với nhau qua cơ chế cung-cầu-giá. Chức năng của cơ quan quản lý là hỗ trợ tốt nhất quá trình tương tác này thông qua cung cấp thông tin chất lượng và truyền thông kịp thời. Các tác nhân của thị trường, chịu sự điều khiển của động lực kinh tế, sẽ tự ra quyết định được coi là hợp lý nhất.

Có thể nói những biến động kinh tế quy mô và tại thời điểm này còn đặt ra yêu cầu thay đổi phương thức điều hành từ kiểm soát sang nghiên cứu-thông tin-thu hút lực lượng thị trường. Hệ thống nghiên cứu-truyền thông tốt sẽ giải quyết đáng kể các vấn đề và tôi thiểu hóa ảnh hưởng tiêu cực từ xa.

\subsection{Nhìn về cuối năm 2008}

Với những điểm rút ra ở trên, trong thời gian tới Việt Nam tiếp tục là điểm đầu tư thu hút quan tâm của cộng đồng tài chính quốc tế, với một số căn cứ quan trọng sau đây.

- Dòng vốn FDI tiếp tục tăng và không có hiện tượng dòng chảy FPI xáo trộn lớn.

- Chính sách thắt chặt tiền tệ tiếp tục được đồng thuận, duy trì và bắt đầu tạo hiệu quả.

- Các phương pháp điều khiển tín hiệu rõ hơn với nền kinh tế, điều mà Việt Nam không làm được trong suốt thời kỳ biến động của nửa đầu năm 2008.

- Việc tăng cường kiểm soát hệ thống siêu quyền lực ngân hàng là bước đi hợp lý.

- Quá trình điều hành cơ chế tỷ giá hỗn hợp đang hình thành và hiệu chỉnh dần độ lệch trong ngắn hạn, phần lớn gây ra bởi tâm lý đầu cơ và bất an. Sự nới lỏng kiểm soát sẽ giúp hệ thống dự trữ quốc gia bền vững hơn.

Với khả năng duy trì các chính sách nhất quán và điều chỉnh ngắn hạn sát theo tín hiệu thị trường, mục tiêu lạm phát của cả năm 2008 ở dưới mức $30 \%$ với sốc tắt dần trong chu kỳ 18 tháng tiếp theo, kèm theo sự duy trì tốc độ tăng trưởng GDP $7 \%$ theo chúng tôi là khả thi./.

\section{TÀI LIÊUU THAM KHẢO:}

1. Ball, Laurence, 1993. "What determine the sacrifice ratio?" NBER Working Paper No. 4306 (1993).

2. Ben Bernake và Cara Lown, 1991. "The credit crunch." Brookings Papers on Economic Activity.

3. Bhatia, Rattan J., 1960. "Inflation, deflation, and economic development." IMF Staff Papers, Vol. 8, No. 1, 1960, pp. 101-114.

4. Barry Eichengreen, 2008. "The real exchange rate and economic growth." Working Paper No. 4, Commission on Growth and Development, World Bank.

5. Chang, R., and A. Velasco, 1999. "Liquidity crises in emerging markets: theory and policy." NBER Working Paper Series No. 7272, National Bureau of Economic Research, Massachusetts.

6. Corsetti, G., P. Pesenti, and N. Roubini, 1998. "What caused the Asian curency and financial crisis?" NBER Working Paper, National Bureau of Economic Research, Massachusetts.

7. Dooley, M. P., 1999. "Origin of the crisis in Asia." In W. C. Hunter, G. G. Kaufman, and T. H. Krueger, The Asian Financial Crisis: Origins, Implications and Solutions. Boston: Kluwer Academic Publishers

8. Dorrance, Graeme S., 1963. "The effect of inflation on economic development." IMF Staff Papers, Vol. 10, No. 1, 1963, pp. 1-47.

9. Dorrance, Graeme S., 1966. "Iflation and growth: the statistical evidence." IMF Staff Papers, Vol. 13, No. 1, 1966, pp. 82-102.

10. Guglielmo Maria Caporale, Peter G. a. Howells, and Alaa M. Soliman, 2004. "Stock market development and economic growth: the causal linkage." Journal of Economic Development, Vol. 29, No. 1, June 2004, pp. 33-50

11. James Riedel, Jing Jin, and Jian Gao, 2007. "How China grows: investment, finance, and reform." Princeton University Press.

12. Johnson, Harry G, 1967. "Is inflation a Retarding Factor in Economic Growth?" In Fiscal and Monetary Problems in Developing States, David Krivine, ed. Frederic A. Praeger Pub., pp. 121-37.

13. Lê Quốc Lý, 2008. "Quan hệ giữa lạm phát với lẵi suất và kiềm chể lạm phát ở Việt Nam." Tạp chi Kinh tế và Dư báo, só tháng 6-2008.

14. McKinnon, R., 1989. "Financial liberalization in Retrospect: interest rate policies in LDCs: In the state of development economics." New York: Blackwell.

15. Marshall, D., 1998. "Understandng the Asian crisis: Systemic risk and coordiation failure." Economic Perspective, Third Quarter: 13-28. Federal Reserve Bank of Chicago. 